\title{
Democratic Theory and Constitutional Design: Hearing Persistent Electoral Minorities
}

Harry Hobbs*

\begin{abstract}
Questions of constitutional design, that is, of structuring the political relationship between dominant and non-dominant communities, are recurrent across the globe. While the particular issues faced by each state are distinct, at their root lies a common problem: how should legal and political institutions and processes be designed to provide minority groups or peoples with the capacity to have their interests heard in the processes of government? In this paper, I explore how democratic theory conceives of, and answers, this fundamental question.
\end{abstract}

\section{Keywords}

Democracy; democratic theory; constitutional design; minorities; countermajoritarian institutions

\section{$1 \quad$ Introduction}

The very essence of democratic governance consists in the absolute sovereignty of the majority... ${ }^{1}$

I am an unashamed majoritarian. I think that the least bad procedure for resolving disagreements within a society...is to let the numbers count. More votes should beat fewer votes when it comes to difficult, contentious social policy decisions, even those about rights. ${ }^{2}$

Questions of constitutional design - of structuring the political relationship between dominant and non-dominant communities - are recurrent across the globe. In the Middle East, minority communities have consistently proposed federalisation as a solution to years of internecine warfare. In Iraq, these efforts culminated in Article 1 of the 2005 Constitution, which for the first time defined the country as a federal state. More recently, in 2016 the Kurdish community of Northern Syria unilaterally declared the establishment of a federal system of government encompassing three self-governing cantons and styled the Democratic Federal System of Northern Syria. ${ }^{3}$ In North Africa, over two decades of civil war and around two

\footnotetext{
* PhD Candidate, Faculty of Law, University of New South Wales; Lionel Murphy Postgraduate Endowment Scholar. Thanks to George Williams, Megan Davis, Kirsty Gover, Mark McMillan, Sean Brennan, Gabrielle Appleby, Patrick Sullivan, Rosalind Dixon and Annabel Johnson for comments on earlier drafts.

${ }^{1}$ A. de Tocqueville, Democracy in America (1835) (Henry Reeve trans, OUP, New York, 1961) p. 182 (Ch XIV).

2 J. Allan, ‘An Unashamed Majoritarian', 27 Dalhousie Law Journal (2004) p. 538.

3 'Syria Civil War: Kurds Declare Federal Region in North', Al Jazeera, 18 March 2016 <http://www.aljazeera.com/news/2016/03/syria-civil-war-kurds-declare-federal-system-north$160317111902534 . \mathrm{html}>$.
} 
million fatalities eventually led to the partition of Sudan, and independence of South Sudan, ${ }^{4}$ though severe conflict has not abated. Partition is neither desirable nor feasible in Sri Lanka, where the country is drafting a new Constitution to ensure "all communities live in harmony". 5 Instead, President Maithripala Sirisena has suggested abolishing the powerful executive presidency and returning to a system of parliamentary democracy. ${ }^{6}$ This process may learn from the Good Friday Agreement in Northern Ireland, which instituted a new consociational democratic order aimed at "enhanc[ing] political and legal inclusiveness".

While these challenges are felt most deeply in divided societies transitioning from authoritarianism or mass conflict, they also arise in consolidated liberal democracies. ${ }^{8}$ In Canada, asymmetric federalism provides Quebec with greater competencies and privileges than the other provinces, but the failure of the Charlottetown Accord has left many questions over the relationship between the state and First Nations and Métis peoples. Likewise, in the United Kingdom, recent amendments to the House of Commons Standing Orders requiring legislation only affecting England to be approved by an English Grand Committee prior to its Third Reading may have resolved the "West Lothian Question", 9 but is attacked by the Scottish National Party as "driving Scotland out of the door". ${ }^{10}$ In Catalonia, dismay over a Constitutional Court decision declaring many provisions of the Statute of Autonomy 2006 unconstitutional, catalysed the modern independence movement. Although that Court has subsequently found unilateral secession would be unlawful, ${ }^{11}$ Catalonia appears poised to hold a referendum on independence in 2017. ${ }^{12}$ Similarly, in Australia, debate continues over the proper constitutional relationship between the non-Indigenous majority and the Aboriginal and Torres Strait Islander minority. Despite broad popular support for amending the Constitution to 'recognise' Aboriginal and Torres Strait Islander peoples, ${ }^{13}$ there is still significant debate over the form recognition should take, what recognition means, and, indeed, whether a referendum to amend the Constitution will even be held. ${ }^{14}$

In a 2008 edited collection exploring the challenge of managing ethnocultural diversity, Sujit Choudhry noted that failing to respond appropriately can have dangerous results, potentially leading to discrimination, forced assimilation, civil war, and even genocide. But even in the absence of violence, failing to manage ethnocultural diversity 'can have a corrosive effect on

\footnotetext{
${ }^{4} \emptyset$. Rolandsen and M.W. Daly, A History of South Sudan: From Slavery to Independence (Cambridge University Press, Cambridge, 2016).

5 'Sri Lanka begins process of writing new constitution to prevent war', $D W, 9$ January 2017

<http://www.dw.com/en/sri-lanka-begins-process-of-writing-new-constitution-to-prevent-war/a-18968845 >

${ }^{6}$ Ibid.

${ }^{7}$ F. Ní Aoláin and C. Campbell, 'The Paradox of Transition in Conflicted Democracies', 27 Human Rights Quarterly (2005) p. 175.

${ }^{8}$ J. Linz and A. Stepan, Problems of Democratic Transition and Consolidation (John Hopkins University Press, Baltimore, 1996) p. 15.

${ }^{9}$ United Kingdom, Standing Orders of the House of Commons (2016) o. 83J.

10 “"English votes” rules used for first time in House of Commons', BBC News, 12 January 2016 <www.bbc.com/news/uk-politics-35295404>.

11 'Spain court rules Catalonia independence votes illegal', $D W, 25$ February 2015

<http://www.dw.com/en/spain-court-rules-catalonia-independence-votes-illegal/a-18279028>. .

12 A. Berwick and T. Cobos, 'Catalonia to hold independence referendum with or without Spain's consent', Reuters, 28 September 2016 <http://www.reuters.com/article/us-spain-catalonia-idUSKCN11Y2FR>.

${ }^{13}$ See e.g. M. Ford and C. Blumer' 'Vote Compass: Most Australians back constitutional recognition for Indigenous Australians', ABC News, 20 May 2016 <http://www.abc.net.au/news/2016-05-20/vote-compassindigenous-recognition/7428030>.

${ }^{14}$ A. Henderson, 'Timing of Indigenous constitutional recognition vote in 2017 pushed back', ABC News, 9 August $2016<$ http://www.abc.net.au/news/2016-08-09/indigenous-recognition-vote-may-still-be-on-thecards/7711516>.
} 
ordinary politics', destabilising both social and institutional trust. ${ }^{15}$ In an era where faith in democratic institutions is falling and ethno-nationalism appears to be on the rise, it is vital that legal and political institutions channel diversity and disagreement in productive ways. While the precise questions faced by each state are distinct, at their root lies a common problem: how can constitutional design ensure that minority groups or peoples are heard in the processes of government? ${ }^{16}$ Formulating the question in this manner suggests that democratic theory may have something to offer.

Democratic theory is a complex subset of political philosophy. It covers a broad range of questions, including definitional disputes over the metes and bounds of the concept, as well as its goals and obligations. Empirical democratic theorists analyse the functioning of democratic regimes in practice, exploring what institutions or decision-making rules are best suited to its operation; normative theorists question its moral foundations, examining whether democratic governance is desirable, and if so, how it can be justified; and, conceptual theorists seek to corral the animating ideals and central features of democracy to better define it. This paper operates on several of these levels, but my major focus is on exploring how democratic theorists-and democratic theory-respond to numerical minorities who constitute historically "marginalised ascriptive groups"17 seeking to have their interests heard in the processes of government.

'Marginalised ascriptive groups' is a multifaceted term. It refers to communities based on hereditary identities, such as culture or ethnicity, and which, based on these identities, are excluded in some way from the broader society. Such social exclusion does not need to be total, but patterns of political and social inequality are nonetheless structured along the lines of group membership. As such, while particular individual members of these communities may not be prevented from participating fully in the economic, social, and political life of the society in which they live; ${ }^{18}$ the community as a whole is prevented from participating on the terms in which they choose to participate. They are "discrete and insular minorities", who, while active and engaged in defence of their interests, "exist[] apart from political decisionmaking". ${ }^{19}$ In some cases, these communities, which differentiate themselves (and are differentiated) from members of the dominant community on the basis of ethnicity or culture, consider themselves sub-state national groups. ${ }^{20}$ In other cases, such marginalised groups seek to protect and promote their unique and distinctive interests from interference by the dominant community, but do not consider themselves to be a 'nation'. Owing to these distinctions, throughout this article I refer to these communities in varying ways. What unites them for my purposes, however, is their status as an identifiable, marginalised community that constitutes a numerical minority within the state they reside.

\footnotetext{
${ }^{15}$ S. Choudhry, 'Bridging Comparative Politics and Comparative Constitutional Law: Constitutional Design in Divided Societies' in S. Choudhry (ed), Constitutional Design for Divided Societies: Integration or Accommodation? (Oxford University Press, New York, 2008) p. 1, 5.

${ }^{16}$ This question is phrased from the state's position and is relevant for accommodating numerical minorities who seek self-determination or greater autonomy not amounting to secession.

${ }^{17}$ M. Williams, Voice, Trust, and Memory: Marginalised Groups and the Failings of Liberal Representation (Princeton University Press, Princeton, 1998) p. 116.

${ }^{18}$ See I.M. Young, 'Five Faces of Oppression' in L. Heldke and P. O'Connor (eds), Oppression, Privilege, and Resistance (McGraw Hill, New York, 2004) pp. 35-49.

${ }^{19}$ J. Waldron, Political Political Theory (Harvard University Press, Cambridge, 2016) p. 242, citing United States v Carolene Products Co. 344 US 144 (1938) p. 152, n 4 (Stone J).

${ }^{20}$ In these cases it is more appropriate to speak of multiple peoples within the state. If secession is neither desirable nor feasible, similar questions of constitutional design will exist.
} 
At one level, democracy appears to offer little for such numerical minorities. After all, popular accounts like those of Alexander de Tocqueville and James Allan cited above, associate the concept so closely with the principle of majority rule that it often seems to be inseparable. This relationship has a rich history in the Western tradition; Aristotle, for example, explained that any state where "the people are in the majority... will necessarily be a democracy". ${ }^{21}$ But democracy is not simply majority rule; it is collective self-rule. Majority rule is merely a decision-making method that is ordinarily best suited to achieving collective self-rule. Indeed, as Part II will demonstrate, majoritarian processes necessarily presuppose the existence of a numerical minority. Where this numerical minority constitutes a marginalised ascriptive group, it may persistently find itself outvoted and its interests ignored. In these cases, collective self-rule is merely majority self-rule. Alternative-democraticarrangements should be devised.

Part III examines eight alternative institutional arrangements proposed by democratic theorists. I divide these into three distinct approaches. First, many democratic theorists propose that the scope of majoritarian institutions' decision-making power should be limited, with certain issues left to be decided by the subgroup itself, or an impartial technocratic body. A second theme argues that majority rule should be deemphasised and the idea of democracy reconceptualised away from the aggregation of preferences. Scholars working within this tradition argue that reasoned deliberation offers greater hope for the unique perspectives and interests of numerical minorities to be heard in the processes of government, but they differ as to whether this can be achieved via enhancing opportunities for citizens to contest government decisions, or establishing open participatory public forums where all voices may be heard. Finally, a third group of theorists recommend working within current representative systems, but tinkering around the edges to enhance the value of numerical minority groups' voting power. Again, these scholars differ in their pronouncements, variously contending that electoral boundaries should be altered, additional votes provided, electoral systems amended, or a certain number of seats in the legislature reserved for members of the group.

Each solution differs in form, but they are all grounded in a desire to ensure that the values and ideals of democracy - collective self-rule - are realised, and each offers valuable insight in exploring how numerical minorities may be heard in the processes of government. It is hoped that this taxonomy of institutional mechanisms for democratic participation will assist constitutional lawyers, democratic theorists, and policy makers in devising appropriate political structures for diverse situations across the globe. This may stem the recent slide towards dangerous nationalism, bolster faltering support for democracy around the world, and assist states reach workable arrangements that allow all of their citizens to be heard by government. Of course, two points should be borne in mind. First, no one mechanism is most suitable. In practice, states adopt a variety of such arrangements calibrated to their unique circumstances. Second, while institutional arrangements are necessary to ensure that minority interests are heard in the processes of government, they are not sufficient. Ultimately a political culture of inclusion and respect, an "ethos of engagement between multiple constituencies", 22 is necessary to breathe life into states composed of dominant and nondominant communities.

\footnotetext{
${ }^{21}$ Aristotle, Politics (Carnes Lord trans, Chicago, University of Chicago Press, 2013) p. 105 (Bk IV, Ch 4).

${ }^{22}$ W. Connolly, 'The Liberal Image of the Nation' in D. Ivison, P. Patton and W. Sanders (eds), Political Theory and the Rights of Indigenous Peoples (Cambridge University Press, Cambridge, 2000) p. 183, 191.
} 
Western democratic theorists, like de Tocqueville and Allan above, have long argued that democracy is inseparable from the principle of majority rule. John Locke, for example, simply assumed that democracy means majority rule when he explained that "a perfect democracy" is one where "the majority having...the whole power of the community naturally in them, may employ all that power in making laws for the community". ${ }^{23}$ Rousseau and Mill adopted similar definitions, arguing respectively that under the social contract, "the vote of the majority always obligates all the others" ${ }^{24}$ and that the ostensible object of democracy involves "giving the powers of government in all cases to the numerical majority". ${ }^{25}$ This view retains some currency; in 1980, Hans Staub declared that "democracy is, by definition, government of the majority", ${ }^{26}$ and, four years later, Elaine Spitz remarked that "it is hard to imagine who else might make such decisions". ${ }^{27}$

However, while majority rule is intertwined with the concept of democracy, it is conceptually distinct. Majority rule is merely a decision-making method; it does not subsume the concept of democracy itself. ${ }^{28}$ Indeed, even the "unashamed majoritarian" James Allan, believes that "the essence of democracy is self-government by the people". ${ }^{29}$ This is a crucial point. For while democracy may be an "essentially contested concept", ${ }^{30}$ at its root lays a simple idea: the people rule collectively. This much is clear etymologically; as a term 'democracy' originates from the Greek dèmokratía, or 'rule of the people', itself a portmanteau of demos (people) and kratos (power). ${ }^{31}$ Rule of the people is thus distinct from other forms of government, such as oligarchia (rule of the few) and monarkhía (rule of one). Collective selfrule has two attributes: influence and control. All of the people (not just a few) must be able to have a say in government in a manner that allows them to impose a direction on that government. ${ }^{32}$ That is, all citizens should be able, if they so wish, to exert meaningful influence on public policy, to "shape the social context in which they live", ${ }^{33}$ such that the government reflects the interests of all citizens and is responsive to changes in those interests. As David Held recognises, democracy is governance "accountable to citizens". ${ }^{34}$

\footnotetext{
${ }^{23}$ J. Locke, Second Treatise of Government (Hackett Publishing, first published 1689, Indianapolis, 1980 ed) p. 68 (Ch X [132]).

${ }^{24}$ J-J. Rousseau, The Basic Political Writings: On the Social Contract (Douglas Cress trans, Hackett Publishing, Indianapolis, $2^{\text {nd }}$ ed, 2011) p, 227 (trans of of: Du contrat social ou principes du droit politique (first published 1762)] (Bk IV Ch 2).

${ }^{25}$ J.S. Mill, Considerations on Representative Government (Parker, Son, and Bourn, London, 1861) p. 163 (Ch 7).

${ }^{26}$ H. Staub, 'The Tyranny of Minorities', 109 Daedalus (1980) p. 159.

${ }^{27}$ E. Spitz, Majority Rule (Chatham House, Chatham, 1984) p. 203. See also H. Arendt, On Revolution (Faber \& Faber, London, 1963) p. 164: majority decision is 'a technical device likely to be adopted almost automatically'.

${ }^{28}$ A. Sen, 'Democracy as a Universal Value', 10 Journal of Democracy (1999) p. 8.

${ }^{29}$ J. Allan, 'Oh that I were made Judge in the Land', 30 Federal Law Review (2002) p. 575.

${ }^{30}$ W.B. Gallie, 'Essentially Contested Concepts' 56 Proceedings of the Aristotelian Society (1955) p. 183.

${ }^{31}$ See generally R. Collier, 'Demos' in P.B. Clarke and J. Foweraker (eds), Encyclopedia of Democratic Thought (Routledge, London, 2001).

${ }^{32}$ P. Pettit, On the People's Terms: A Republican Theory and Model of Democracy (Cambridge University Press, New York, 2012) p. 22.

${ }^{33}$ T. Pogge, 'Creating supra-national institutions democratically: Reflections on the European Union's "Democratic Deficit”' 5 The Journal of Political Philosophy (1997) p. 179.

${ }^{34}$ J-P. Gagnon, 'An Interview with Professor David Held: Exploring the Concepts of Cosmopolitanism and Democracy' 1 Democratic Theory (2011) p. 1. See also P. Schmitter and T.L. Karl, 'What Democracy is... and is not' 2 Journal of Democracy (1991) p. 76. In modern representative democracies, it is the act of electing members of Parliament that the voter exerts her will and holds her representative accountable: H. Pitkin, The Concept of Representation (University of California Press, Berkeley, 1967) p. 43.
} 
Josiah Ober's reconstruction of the original Greek understanding of democracy supports this broad interpretation. Ober argues that ancient Greek accounts did not centre on the peoples' "monopolistic control of pre-existing constitutional authority", but as a regime in which "the demos gains a collective capacity to effect change in the public realm". ${ }^{35}$ Democracy as "the empowered demos", ${ }^{36}$ means that all the people, from "the poorest he that is in England" to "the greatest he" ${ }^{37}$ — not just a majority - must have a capacity to act. Reducing democracy to a voting-rule therefore "elides much of the value and potential of democracy". ${ }^{38}$

To say that democracy requires collective self-rule is not to say that collective self-rule comes in a single form, rather, it can be instrumentalised in diverse ways. It may take the form of a federal state with a bicameral legislature and elected executive, or a unitary state with a unicameral legislature and executive responsible to that legislative branch. Members of the judiciary might be elected rather than appointed, while vice versa, members of one legislative chamber may be appointed, not elected; voting may or may not be compulsory; and, the power of government may be controlled by a single written constitution or a series of uncodified statutes and political conventions. Notwithstanding these significant discrepancies, so long as all of the people have a collective capacity to influence government, collective selfrule is realised. Allan accepts this, he simply believes that "letting the numbers count", ${ }^{39}$ is ordinarily "the least bad procedure" 40 for ensuring that government is accountable to citizens and therefore, for securing collective self-rule.

\subsection{Majority Rule and Numerical Minorities}

I am generally in agreement with Allan. As a decision-making method, majority rule has definite advantages. Social choice theorists have demonstrated that, between two alternatives, majority rule is the only decision-making procedure which satisfies four relevant conditions. It is: decisive - regardless of preference distribution there is always a clear winner; anonymous - the identity of each voter is immaterial; neutral - both outcomes are treated the same as reversing each individual preference reverses the group preference; and, positively responsive - a tied decision can be reversed by one voter changing their preference ordering. ${ }^{41}$ No other collective decision-making rule satisfies these four conditions: unanimity rule violates decisiveness; weighted majority rule violates anonymity; and supra-majority rule violates neutrality and positive responsiveness (if weighted towards the status quo). ${ }^{42}$ Putting to one-side issues of preference cycling and additional alternatives, ${ }^{43}$ majority rule expresses

\footnotetext{
35 J. Ober, 'The Original Meaning of "Democracy": Capacity to do things, not Majority Rule' 15 Constellations (2008) p. 7.

${ }^{36}$ Ibid.

${ }^{37}$ Colonel Rainborough in the Putney Debates, 1647: C. Firth (ed), Sir William Clarke, The Clarke Papers (Camden Society, London, 1901) Vol I, p. 301.

${ }^{38}$ Ober, supra note 35, p. 3.

${ }^{39}$ J. Allan, 'Siren Songs and Myths in the Bill of Rights Debate' 49 Papers on Parliament (2008) p. 5.

${ }^{40}$ Allan, supra note 2, p. 538 (emphasis added).

${ }^{41}$ K. May, 'A Set of Independent Necessary and Sufficient Conditions for Simple Majority Decisions' 20 Econometrica (1952) p. 680.

${ }^{42}$ N. Miller, 'Majority Rule and Minority Interests' in I. Shapiro and R. Hardin (eds) Political Order: Nomos XXXVIII (New York University Press, New York, 1996) p. 207, 215; H. Kelsen, 'On the Essence and Value of Democracy' in A. Jacobson and B. Schlink (eds), Weimar: A Jurisprudence of Crisis (University of California Press, Berkeley, 2000) p. 84, 86.

${ }^{43}$ K. Arrow, Social Choice and Individual Values (Yale University Press, New Haven, 1951). Cf .G. Mackie, Democracy Defended (Cambridge University Press, Cambridge, 2000).
} 
the fundamental political equality of citizens, ${ }^{44}$ as well as maximising the number of people who exercise self-rule, ${ }^{45}$ and, epistemically, potentially leads to better outcomes. ${ }^{46}$

All political communities need a decision-rule by which preferences are aggregated into collective choice, ${ }^{47}$ and majority rule is ordinarily the least bad procedure. But this is different from saying that it is always the least bad procedure, or that majority rule will always secure collective self-rule. The problem is that majority rule necessarily presupposes the existence of a minority. This poses a conundrum for democratic theory, for in these circumstances how can we say that the outvoted exercise self-rule? For democratic theorists like Rousseau, this question never eventuates, as people are not asked whether they approve of a legislative proposal, but whether it conforms to the "general will", the common and objective "indestructible"48 "will of the people". As Rousseau explained, "when...the opinion contrary to mine prevails, this proves merely that I was in error, and that what I took to be the general will was not so"; ${ }^{49}$ although I have been outvoted, I remain "as free as before" because I am ruling myself, having placed myself "under the supreme direction of the general will". 50 However, even Rousseau acknowledged that in some cases the numerical majority may incorrectly ascertain the general will, and so introduced the mythical "Legislator" who seemingly has superior access to the content of the general will and is responsible for persuading citizens to mould their wills into conformity with reason. ${ }^{51}$ In a diverse and heterogeneous society without an omniscient, Platonic philosopher king, the general will is not ascertainable. ${ }^{52}$ If we dismiss the notion then that the will of the majority is the will of all, ${ }^{53}$ majority rule appears to offer little for numerical minorities who are reduced to "political losers". 54

\footnotetext{
${ }^{44}$ N. Riemer, 'The Case for Bare Majority Rule' 62 Ethics (1951) p. 17; J. Waldron, Law and Disagreement (Oxford University Press, New York, 1999) pp. 114-15; W. Sadurski, Equality and Legitimacy (Oxford University Press, London, 2008) Ch 2; J. Waldron, 'A Majority in the Lifeboat' 90 Boston University Law Review (2010) p. 1055.

${ }^{45}$ Kelsen, supra note 42, pp. 87-88.

${ }^{46}$ See e.g. M. de Condorcet, 'Essay on the Application of Mathematics to the Theory of Decision-Making' in K Baker (ed), Condorcet: Selected Writings (Macmillan Press, New York, 1976) pp. 48-49; L. Hong and S. Page, 'Groups of Diverse Problem Solvers Can Outperform Groups of High-Ability Problem Solvers' 101

Proceedings of the National Academy of Sciences (2004) p. 1635; H. Landemore, Democratic Reason: Politics, Collective Intelligence, and the Rule of the Many (Princeton University Press, Princeton, 2012). Cf. J. Brennan, Against Democracy (Princeton University Press, Princeton, 2016) pp. 172-203.

${ }^{47}$ Miller, supra note 42, p. 213.

${ }^{48}$ Rousseau, supra note 24, p. 224 (Bk IV Ch 1).

${ }^{49}$ Ibid., p. 227 (Bk IV Ch 2).

${ }^{50}$ Ibid., p. 164 (Bk 1 Ch 6).

${ }^{51}$ Ibid., p. 180 (Bk II Ch VI). See further H. Fireside, 'The Concept of the Legislator in Rousseau's Social Contract' 32 The Review of Politics (1970) p. 192.

${ }^{52}$ Nadia Urbinati argues that Rousseau's conception is only plausible within a homogenous demos: N. Urbinati, Representative Democracy: Principles and Genealogy (University of Chicago Press, Chicago, 2006) pp. 44, 136. ${ }^{53}$ A position ably expressed by E.J. Sieyès, Political Writings (M. Sonenscher trans, Hackett Publishing, Indianapolis, 2003) pp. 39-40 [trans of Vues sur les moyens d'exécution dont les représentants de la France pourront dispose en 1789 (first published, 1789) the general interest is 'one interest among the various individual interests that is common to the largest number of voters'. Despite drawing on Rousseau for his conception of democracy, Kelsen refers to this idea as a 'fiction': Kelsen, supra note 42, p. 101. See also P. Pettit, 'Republican Freedom and Contestatory Democratization' in I. Shapiro and C. Hacker-Cordon (eds), Democracy's Value (Cambridge University Press, Cambridge, 1999) p. 163, 177.

${ }^{54}$ C. Anderson et al, Losers' Consent: Elections and Democratic Legitimacy (Oxford University Press, New York, 2005) p. 2.
} 
'So what?' Allan might ask. 'That is democracy'. This is true. Absent unanimity or consensus decision-making (a form of decision-making adopted by many Indigenous communities), ${ }^{55}$ some number of people will be 'political losers' in any and every decision. If democracy is, as Joseph Schumpeter's seminal definition would have it, nothing more than an "institutional arrangement for arriving at political decisions in which individuals acquire the power to decide by means of a competitive struggle for the people's vote", ${ }^{56}$ then no normative weight should be accorded to the existence or policy preference of electoral minorities.

Democratic theorists are not entirely unreceptive to the concern of electoral minorities. After all, if electoral minorities lose faith in the democratic system, they may choose not to take part in democratic institutions, and perhaps even choose to subvert them. The viability and continuation of democratic systems therefore depends, in part, on the losers' consent. ${ }^{57}$ This requires a Rawlsian "overlapping consensus", ${ }^{58}$ or a "sense of belonging together", 59 within the society, such that all persons "feel that they are part of the same destiny and have a share in the same general public", 60 but it also necessitates institutional forms that empower electoral minorities in some manner, such as through the principle of the loyal opposition. ${ }^{61}$ Such mechanisms are intended to ensure that a temporary political majority does not undermine the democratic process to prevent today's electoral losers from becoming tomorrow's electoral winners. ${ }^{62}$ But is this the case? Can numerical minorities become persistent electoral minorities, and how do democratic theorists deal with these cases?

\subsection{Do Persistent Electoral Minorities Exist?}

Pluralist democratic theorists have traditionally discounted the existence of persistent electoral minorities. For Robert Dahl, in "a large and pluralistic society" majorities are "likely to be unstable and transitory" and therefore "politically ineffective". ${ }^{63}$ Rather, "constantly shifting constellations of various minority interests" $" 64$ will coalesce around certain issues before breaking apart and rearranging themselves on other issues. As such, on "matters of specific policy" a majority "rarely, if ever, rule[s]"; fear of majority rule is therefore "founded

\footnotetext{
${ }^{55}$ See e.g. I. Watson, Raw Law (Routledge, London, 2015) p. 17; K. Horn-Miller, 'What does Indigenous Participatory Democracy Look Like? Kahnawà:ke's Community Decision Making Process' 18 Review of Constitutional Studies (2013) pp. 116-118.

56 J. Schumpeter, Capitalism, Socialism and Democracy (Harper \& Brothers, New York, 1942) p. 269.

${ }^{57}$ R. Nadeau and A. Blais, 'Accepting the Election Outcome: The Effect of Participation on Losers' Consent' 23 British Journal of Political Science (1993) p. 553; Anderson et al, supra note 54, p. 13.

${ }^{58}$ J. Rawls, Political Liberalism (Cambridge University Press, Cambridge, 1993) p. 165. See also M. Keating, Plurinational Democracy: Stateless Nations in a Post-Sovereignty Era (Oxford University Press, New York,, 2001) p. 8 .

${ }^{59}$ A. Mason, 'Political Community, Liberal-Nationalism and the Ethics of Assimilation' 109 Ethics (1999) p. 266.

${ }^{60}$ Urbinati, supra note 52, p. 136.

${ }^{61}$ On loyal opposition see Waldron, supra note 19, pp. 93-124. On the need for counter-majoritarian mechanisms see: R. Dahl, A Preface to Democratic Theory (University of Chicago Press, Chicago, 1956) p. 36; J.H. Ely, Democracy and Distrust: A Theory of Judicial Review (Harvard University Press, Boston, 1980) pp. 73, 87; I. Shapiro, The State of Democratic Theory (Princeton University Press, Princeton, 2003) p. 76. Aristotle, supra note 21, p. 106 (Bk IV Ch 4); J. Madison, Federalist No. 51 (1788) in D. Wootton (ed), The Essential Federalist and Anti-Federalist Papers (Hackett Publishing, Indianapolis, 2003) pp. 248-9.

${ }^{62}$ I. Shapiro, The Real World of Democratic Theory (Princeton University Press, Princeton, 2010) p. 20; E. Latham 'The Group Basis of Politics: Notes for a Theory' 46 American Political Science Review (1952) p. 391.

${ }^{63}$ Dahl, supra note 61, p. 30.

${ }^{64}$ R. Pildes, 'Democracy and the Representation of Minority Interests' in F. Bastida (ed), Fundamentos: La Representación Política (Asturias, 2004) p. 2. Available at: <www.unioviedo.es/constitucional/fundamentos/ tercero/originales/Pildes.pdf>
} 
upon a misconception of the probabilities permitted by political reality". ${ }^{65}$ David Tubman also emphasises the "protean complex of crisscrossing relationships" and the "notion of multiple or overlapping membership" that characterise modern society. In view of this social fact, and "the diversity of an individual's activities and his attendant interests", Tubman argues, "no single group affiliation accounts for all of the attitudes or interests of any individual except a fanatic or a compulsive neurotic". ${ }^{66}$ Hans Kelsen made a similar point, arguing that majority rule incentivises minority groups to overcome "the numerous forces within society that drive it into divisions and ruptures", amalgamate, and secure electoral victory. ${ }^{67}$ If a majority truly acts as a dictator and condemns a minority "to irrelevance", Kelsen believes the minority group would renounce its "participation in the formation of the will of the community", "depriv[ing] the majority... of its very character". ${ }^{68}$ For these theorists then, the problem of persistent electoral minorities simply does not arise; no person is denied self-rule because, on specific policy proposals, all members of society take turns being ruler and ruled. ${ }^{69}$

Simple majority rule does not necessarily make intensity of policy preferences visible. ${ }^{70}$ For example, A, B, and C may prefer P1 > P2, while D may prefer P2 > P1. This does not, however, tell us how important $\mathrm{P} 1$ or $\mathrm{P} 2$ is for each individual or group; $\mathrm{A}, \mathrm{B}$, and $\mathrm{C}$ may marginally prefer P1, while P2 may be vitally important for D. In a situation where A, B, C and $\mathrm{D}$ all have one vote, $\mathrm{P} 1$ will be enacted, as it commands the broadest support. But, if D is particularly engaged and animated (or if voting is not compulsory), it may be able to trade-off support for other policies (P3, P4, etc.) to ensure P2 is adopted. Democratic theorists are particularly concerned about this common feature of the democratic process, ${ }^{71}$ as it appears to indicate that rather than tyranny of the majority, it is tyranny of an intense minority and an apathetic majority that should most concern committed democrats. ${ }^{72}$

In some respects, these theorists are correct. In the United States, the rise of party activists and intra-party participatory nominating processes, has contributed to the selection of more ideologically extreme candidates. ${ }^{73}$ Likewise, declining party membership in Australia and the United Kingdom has pushed political parties to experiment with more open and participatory candidate selection policies in order to mitigate the influence of factional groups. ${ }^{74}$ At the same time, despite some research questioning the effectiveness of lobbying, ${ }^{75}$

\footnotetext{
${ }^{65}$ Dahl, supra note 61, p. 25, fn. 34. See also A.J. McGann, 'The Tyranny of the Supermajority: How Majority Rule Protects Minorities' 16 Journal of Theoretical Physics (2004) p. 71.

${ }^{66}$ D. Tubman, The Governmental Process: Political Interests and Public Opinion (Alfred A. Knopf, New York, 1951) p. 508 (emphasis added).

${ }^{67}$ Kelsen, supra note 42, p. 102.

${ }^{68}$ Ibid. Despite Kelsen's suggestion, for many marginalised ascriptive groups secession is neither desirable nor feasible. In these circumstances, democratic theory demands that political and legal institutions are established to enable that minority group to have its interests heard in the processes of government.

${ }^{69}$ Aristotle, supra note 21, pp. 26-7 (Bk II Ch 2).

${ }^{70}$ J. Buchanan and G. Tullock, The Calculus of Consent (University of Michigan Press, Ann Arbor, 1962) p.

135. See also Sadurski, supra note 44, pp. 50-51.

${ }^{71}$ See discussion in Miller, supra note 42, p. 207.

${ }^{72}$ Dahl, supra note 61, p. 99; Kelsen, supra note 42, p. 102; I. Shapiro, Democratic Justice (Yale University Press, New Haven, 1999) p. 33; Staub, supra note 26, p. 159: 'minorities of all kinds have become the decisionmakers; they dominate, tyrannise, or terrorise the majority, which appears principally as a conglomerate of constantly changing minorities'.

${ }^{73}$ G. Layman, T. Carsey and J. Horowitz, 'Party Polarization in American Politics: Characteristics, Causes and Consequences' 9 Annual Review of Political Science (2006) p. 99.

${ }^{74}$ A. Gauja, 'The "Push" for Primaries: What Drives Party Organisational Reform in Australia and the United Kingdom? 47 Australian Journal of Political Science (2012) p. 655.

${ }^{75}$ F. Baumgartner et al, Lobbying and Policy Change: Who Wins, Who Loses, and Why (University of Chicago Press, Chicago, 2009).
} 
interest groups continue to spend vast sums seeking to exert policy or legislative change. ${ }^{76}$ Successful efforts, like the mining industry's campaign against the Australian Labor Government's resource super profits tax, ${ }^{77}$ or successive failure to achieve healthcare reform in the United States, ${ }^{78}$ suggest that committed minority groups are capable of influencing significant change.

Likewise, in recent years, a number of scholars exploring the political impact of income inequality have explained how electoral democracies fail to adequately facilitate collective self-rule. Rather, empirical evidence suggests that elected officials are more likely to be accessible and responsive to the views of a minority of affluent constituents rather than all citizens. ${ }^{79}$ John McCormick's reconstruction of Machiavelli as a theorist of popular democracy, concerned with extra-electoral checks to constrain socio-economic elites and enable those "most vulnerable to participate in collective decisions" ${ }^{80}$ indicates that this dynamic was perhaps better understood in earlier times. ${ }^{81}$ As Machiavelli presciently noted, "the [privileged] few always behave in the mode of the few". 82 This is a concerning development and care should be taken to ensure that the economically marginalised are able to participate in collective decisions on the same level as wealthier citizens. Restrictions on campaign finance legislation and political donations laws are a first step in equalising the playing field. ${ }^{83}$ Nonetheless, while McCormick's intervention is helpful, his class-based cleavage too readily accepts 'the people' as a homogenous unit (a critique McCormick makes at contemporary constitutionalists), ${ }^{84}$ and elides significant distinctions within this heterogeneous group.

This blindness is not uncommon. ${ }^{85}$ Iris Marion Young has critiqued political philosophers for failing to comprehend the concept of the social group, instead conceiving it either as an aggregate or association, "both of which are methodologically individualist concepts". ${ }^{86}$ The

\footnotetext{
${ }^{76}$ In the United States, there are 9,726 federally registered lobbyists, and lobbying accounted for \$779 million in the second quarter of 2016: A. Goodwin and E. Baccellieri, 'Number of registered lobbyists plunges as spending declines yet again', Open Secrets, 9 August 2016 <https://www.opensecrets.org/news/2016/08/ number-of-registered-lobbyists-plunges-as-spending-declines-yet-again/>

${ }_{77}$ A. Mitchell, 'Lobbying for the Dark Side' 71 Meanjin (2012) p. 39.

${ }^{78}$ See e.g. G. Belkin and J. Morone (eds), The Politics of Health Care Reform: Lessons from the Past, Prospects for the Future (Duke University Press, Durham, 1994).

${ }^{79}$ L. Bartels, Unequal Democracy: The Political Economy of the New Gilded Age (Princeton University Press, Princeton, 2008); D.V. Reybrouck, Against Elections: The Case for Democracy (Vintage, London 2016); J. McCormick, Machiavellian Democracy (Cambridge University Press, Cambridge, 2011) p. 98.

${ }^{80}$ D. Dyzenhaus, 'Response to Ian Shapiro “On Non-Domination”" 62 University of Toronto Law Journal (2012) p. 345.

${ }^{81}$ McCormick, supra note 79, pp. 6, 31, 86, 112.

${ }^{82}$ N. Machiavelli, Discourses on Livy (Harvey Mansfield and Nathan Tarcov trans, University of Chicago Press, Chicago, 1996) p. 25 (Bk I Ch 7).

${ }^{83}$ High Courts in Australia, Canada and the United Kingdom have upheld restrictions on campaign finance legislation and political donation laws: McCloy $v$ NSW [2015] HCA 34; Harper v Canada (Attorney-General) [2004] 1 SCR 827; R (Animal Defenders) v Culture Secretary [2008] AC 1312, while moves in the United States to overturn Citizens United v FEC, 588 US 310 (2010) are continuing.

${ }^{84}$ McCormick, supra note 79, p. 12.

${ }^{85}$ See also F. Rosen, 'Majorities and Minorities: A Classical Utilitarian View' in J. Chapman and A. Wertheimer (eds), Majorities and Minorities: Nomos XXXII (New York University Press, New York, 1990) p. 24, 32. Rosen warns that conceptualising democratic government as majority rules confuses, and obscures the fact that 'even in a democratic government all ruling is in effect minority rule'. The 'task of democratic constitutionalism' for Rosen, is to protect and secure 'the majority from misrule and oppression under a system of minority rule'. ${ }^{86}$ I.M. Young, Justice and the Politics of Difference (Princeton University Press, Princeton, 1990) p. 43. On the idea of 'societal cultures' see W. Kymlicka, Multicultural Citizenship (Oxford University Press, New York, 1995) pp. 75-93.
} 
aggregate model reduces a social group to "a mere set of attributes", red hair, blue eyes, black skin, etc., while the association model sees individuals as constituting groups, implicitly treating the individual "as ontologically prior to the collective". ${ }^{87}$ The cross-cutting interests identified by Dahl, Tubman, Kelsen and others, accords with this approach. Each scholar recognises interest groups not social groups. The atomistic individual may have a range of policy preferences and associate with other individuals to advocate for those preferences, but a social group is not simply a collection or aggregation of people, for it is "more fundamentally intertwined with the identities of the people described as belonging to them" and is defined "by a sense of identity" ${ }^{88}$ According to Young, social groups "constitute individuals", for "a person's particular sense of history, affinity, and separateness, even...mode of reasoning, evaluating, and expressing feeling, are constituted partly by her or his group affinities"; "they differentiate themselves from or are differentiated by at least one other group according to these cultural forms". ${ }^{90}$ Melissa Williams agrees with Young's definition of social groups, and contrasts it with pluralist political theorists' interest groups. For Williams, membership in a "marginalised ascriptive group" is radically different from membership in an interest group: "it is involuntary, immutable, and dichotomous, whereas membership in an interest group is voluntary, shifting, and a matter of degree". ${ }^{91}$

Elucidation of the distinctions between interest groups and social groups highlights the flawed approach of democratic theorists who contend that persistent electoral minorities do not exist in democracies. For example, the precarious demographic position of most Aboriginal and Torres Strait Islander peoples within the Australian settler-state weakens their ability to effectively participate in the democratic system and influence its institutions towards their aspirations. ${ }^{92}$ Indigenous leaders lament feelings of disempowerment and alienation from the governmental process, Indigenous policy makers document their concern over the democratic deficit within the sector, and Indigenous aspirations and demands are all-too-often either relegated or ignored entirely by majoritarian processes. ${ }^{93}$ Similar complaints are levied by numerical minorities who constitute marginalised communities across the globe.

Of course, sometimes the political system does work for numerical minorities, and they can protect themselves by emphasising ties that bind the interests of the dominant community to their own. But intermittent (partial) success is often met with significant political backlash. To continue the Australian example, enactment of the Native Title Act 1993 (Cth), which created a narrow but clear legal pathway for Indigenous groups to ensure Australian law respects and protects their property rights over their traditional land, was followed by "bucketloads of extinguishment", ${ }^{94}$ and the promised social justice package remains illusory. This is not to denigrate the many committed members of minority groups who agitate to have their distinctive interests heard in the processes of government, or to dismiss their effort. It is

\footnotetext{
${ }^{87}$ Young, supra note 86, p. 44.

${ }^{88}$ Ibid., pp. 43-44. See also I.M. Young, Inclusion and Democracy (Oxford University Press, New York, 2000) pp. 87-92.

${ }^{89}$ Young, supra note 86, p. 45

${ }^{90}$ Ibid., p. 186.

${ }^{91}$ Williams, supra note 17 , p. 116.

92 N. Pearson, A Rightful Place (Quarterly Essay, No. 55, 2014) 38.

${ }^{93}$ See L. Behrendt, Achieving Social Justice: Indigenous Rights and Australia's Future (Federation Press, Sydney, 2003) p. 15; M. Davis and M. Langton (eds), It's Our Country: Indigenous Arguments for Meaningful Constitutional Recognition and Reform (Melbourne University Press, Melbourne, 2016); M. Davis, 'The United Nations Declaration on the Rights of Indigenous Peoples' 6:30 Indigenous Law Bulletin (2007) p. 6; M. Davis, 'Listening but not Hearing' 51 Griffith Review (2016) p. 73;

${ }^{94}$ J. Highfield, Interview with Tim Fisher, Deputy Prime Minister of Australia (Radio Interview, 4 September 1997); Native Title Amendment Act 1998 (Cth).
} 
merely acknowledging that brute demography means the system is structured against them; they "cannot protect themselves in [majoritarian] politics". 95

As feminist theorists have warned in relation to gender, however, it is necessary to avoid the trap of essentialising members of minority communities. ${ }^{96}$ All groups are heterogeneous, with a wide diversity of political values and worldviews. Just as Dahl argued, not all members will be electoral losers on every issue. Nonetheless, among this diversity of interests, commonalities of culture, background and experience, particularly experience as a minority group within the larger polity, draws members together, and it is on law and policy fragmented along, for example, Sinhalese-Tamil, Francophone-Anglophone, pakeha-Māori, Catalan-Castilian or Aboriginal-non-Aboriginal lines, that this cleavage poses problems. But assuming members of the minority group do not subvert the state's democratic institutions, is this a problem for democracy?

\subsection{Persistent Electoral Minorities and Political Legitimacy}

Consideration of persistent electoral minorities poses a challenge to procedural or instrumental accounts of democratic theory. If democracy is merely an "institutional arrangement for arriving at political decisions", ${ }^{97}$ then questioning whether the policy preferences of an elector are enacted asks the wrong question. All that should matter is that the political resources are distributed equally, that every person has one vote. As I have noted, however, democracy is more than a decision-making rule, and while democracies can come in many shapes and sizes they all must be structured so as to ensure collective (and not merely majority) self-rule. Majority decision is very likely to be the presumptive decision-making method, but institutional arrangements must exist to empower numerical minorities. Where persistent electoral minorities exist, undifferentiated majority rule will be inappropriate.

A number of democratic theorists recognise the paucity of the instrumental account. Anna Stilz argues that a fundamental condition of democracy entails the government looking out for the basic interests of all of its citizens, not just a subset. Where a majority routinely ignores the interests of a minority it acts illegitimately. ${ }^{98}$ Equally, Thomas Christiano contends that the idea that "the democratic process confers legitimacy on the outcomes of the decisionmaking process" is rocked by the existence of "persistent minorities". 99 Drawing on the notion of public equality, Christiano argues that proceduralist accounts do "not take sufficiently seriously the very interests that individuals have in having a say in their society". ${ }^{100}$ As a persistent minority "lacks the means for effecting law and policy", ${ }^{101}$ their ability to play a role in shaping their society is diminished, a problem that the group "could not fail to be aware" of. ${ }^{102}$ Though they may enjoy all of the formal-legal privileges of citizenship, their position ensures they remain "functionally excluded from the political

\footnotetext{
${ }^{95}$ M. Tushnet, Taking the Constitution Away from the Courts (Princeton University Press, Princeton, 1999) p. 159.

${ }^{96}$ See Young, supra note 86, p. 48; A. Phillips, The Politics of Presence (Oxford University Press, New York, 1995) p. 55.

${ }^{97}$ Schumpeter, supra note 56, p. 269.

98 A. Stilz, Liberal Loyalty: Freedom, Obligation and the State (Princeton University Press, Princeton, 2009) pp. 94-95.

${ }^{99}$ T. Christiano, The Constitution of Equality (Oxford University Press, New York, 2010) p. 288.

${ }^{100}$ Ibid., p. 296.

101 T. Christiano, 'Reply to Critics of The Constitution of Equality' 5:3 Journal of Ethics \& Social Philosophy (2011) pp. 12-13.

102 J. Hyland, Democratic Theory: The Philosophical Foundations (Manchester University Press, Manchester, 1995) p. 88.
} 
process, and thus effectively excluded from the life of the 'true' political community". ${ }^{103}$ Reflecting on these positions, Jeff Spinner-Halev has argued that the existence of persistent minorities "does not necessarily make a state illegitimate, but it does raise the possibility of partial legitimacy". 104

This notion of partial legitimacy can be illuminated further by exploring the conceptual distinctions between majority tyranny and persistent electoral minorities, for although these terms describe very different pathologies, the consequences for the legitimacy of the democratic state are similar. Tyranny of the majority involves the arbitrary interference in the lives of a minority, in vicious and systemic ways. Conversely, persistent electoral minorities may be subject to decisions of a principled and egalitarian majority whom takes the minority's interests into account and enacts policies that they consider beneficial for the minority. While this latter case is clearly preferable, it remains problematic, as it is likely that the majority acts under its own conception of the minority's interests, which may differ substantially. ${ }^{105}$ Even in these cases, the majority has the capacity to interfere on an arbitrary basis in certain choices that the minority is in a position to make. ${ }^{106}$ This point demonstrates that persistent electoral minorities will only be able to exercise collective self-rule if they are able to influence and direct government; that is, if their interests are heard in the processes of government. Recognising that at its root, democracy means collective self-rule reveals this problem and leads us to consider institutional reform.

\section{$3 \quad$ How Can Persistent Electoral Minorities Be Heard?}

Majority rule may be deeply associated with democracy, but it is conceptually distinct. If democracy means the collective self-rule of the people, majority rule is merely an instrument towards that goal; ${ }^{107}$ and "there is no reason to think that there is one best rule of collective decision". ${ }^{108}$ Rather, different rules may be more or less appropriate for different activities, depending on the nature of the participants and the issues involved. ${ }^{109}$ The "creative challenge" that some democratic theorists have taken up, is to develop processes that enhance the ability of marginalised ascriptive groups' to have their interests heard in the processes of government, "in ways that are more, rather than less, compatible with democracy."110

This Part provides a taxonomy of eight institutional attempts to achieve this goal. They can be broadly categorised into three alternative approaches. The first argues that the scope of majoritarian institutions' decision-making power should be limited, with certain issues left to be decided by the group itself, or an impartial technocratic body that makes decisions on the basis of some objective standard. The second suggests that aggregative democracy is per se unsuitable for states with persistent electoral minorities, and representative institutions should be transformed into sites of reasoned deliberation or forums of contestation to enable

\footnotetext{
${ }^{103}$ H.N. Hirsch, 'The Threnody of Liberalism' 14 Political Theory (1986) p. 437.

104 J. Spinner-Halev, Enduring Injustice (Cambridge University Press, Cambridge, 2012) p. 133.

105 Christiano, supra note 99, pp. 289-292.

${ }^{106}$ P. Pettit, Republicanism: A Theory of Freedom and Government (Oxford University Press, New York, 1997) p. 52

107 J. Dewey, The Public and its Problems: An Essay in Political Inquiry (Penn State University Press, University Park, 2012 ed, first published 1927) p. 120.

108 Shapiro, supra note 72, pp. 32-35.

${ }^{109}$ R. Dworkin, Freedom's Law: The Moral Reading of the American Constitution (Harvard University Press, Cambridge, 1996) p. 139.

${ }^{110}$ I. Shapiro, 'Group Aspirations and Democratic Politics' 3 Constellations (1997) p. 321.
} 
members of such groups to be heard. The third accepts majority rule as a preferable decisionmaking method, but aims at enhancing the voice of marginalised ascriptive groups within representative institutions by amending electoral machinery. Although each form of minority inclusion explores this issue from a distinctive angle, they all reflect an understanding that democracy requires all voices to be heard in the processes of government. In this sense, each seeks to instrumentalise a different understanding of collective self-rule. Of course, institutional alterations are a necessary but not sufficient criterion for change; ultimately cultural change is required to ensure that the majority will heed that voice. ${ }^{111}$

\subsection{Limiting the Scope of Majoritarian Decision-Making Power}

A common approach to protecting and promoting the interests of marginalised ascriptive groups involves restraining the scope of majoritarian institutions' decision-making power to preclude its operation within areas of particular concern of such groups. Decisions over certain issues are either taken out of the political sphere and placed in the hands of impartial, technocratic or managerial bodies, or removed to smaller, autonomous political subunits. While each approach aims to "alleviate the vulnerability of minority cultures to majority decisions," 112 the means embraced vary substantially. In the former case, the voices of all ordinary citizens are excised from the deliberative body, while in the latter circumstance a numerical minority is permitted to decide certain issues for itself. In this case, the extent of voice is significant, as the numerical minority is entitled to full decision-making power over certain areas, and a guaranteed voice in the central government.

\subsubsection{Technocratic Democracy}

Constitutional or statutory provisions that channel decision-making (and not merely dispute resolution) away from majoritarian bodies towards impartial bureaucratic, administrative or managerial bodies are common throughout the world, though they are not necessarily conceived as protecting marginalised communities. Rather, they are often seen as a response to the increasing complexity of governance and consequent requisite technological expertise required to understand and develop sound public policy, ${ }^{113}$ or a reaction against delay and compromise inherent to political bargaining. ${ }^{114}$ Nonetheless, in inhibiting the 'passions' of the people, aspects of technocratic democracy have been promoted as enhancing the capacity of marginalised groups to have their interests heard.

The rise of technocratic democracy is identified primarily in the global shift of monetary and banking policy from elected representatives to bodies staffed by unelected economists. In Canada, the Bank of Canada is responsible for regulating credit and currency "in the best interests of the economic life of the nation" and "promot[ing] the economic and financial welfare" of the country, ${ }^{115}$ all tasks that prior to 1938 were undertaken by government. The Canadian approach is not unique: central banks in most developed nations are structured so as

\footnotetext{
${ }^{111}$ G-U. Charles, 'Dissent, Diversity, and Democracy: Heather Gerken and the Contingent Imperative of Minority Rule’ 48 Tulsa Law Review (2013) p. 495.

112 Kymlicka, supra note 86, p. 109.

${ }^{113}$ F. Fischer, Technocracy and the Politics of Expertise (Sage, Newbury Park, 1990). Boswell disputes this instrumental account, contending that expert knowledge plays a symbolic function, both legitimising a government's claim to authority, and substantiating a political party's policy preferences: C. Boswell, The Political Uses of Expert Knowledge: Immigration Policy and Social Research (Cambridge University Press, Cambridge, 2009) p. 7.

${ }^{114}$ P. Silva, In the Name of Reason: Technocrats and Politics in Chile (Penn State University Press, University Park, 2009) p. 105.

${ }^{115}$ Bank of Canada Act (RSC, 1985 c. B-2), preamble.
} 
to be independent from political interference. ${ }^{116}$ In some cases, technocratic elements have penetrated further into the political domain. In Latin America, for instance, the appointment of economic technocrats to key state positions began in the 1980s and accelerated with neoliberal reforms in the 1990s. The power of these technocrats varies across states, but research suggests that they have been successful in advancing their own policy preferences, significantly altering institutional arrangements and the distribution of resources across society, even when it conflicts with the position of a democratically elected government. ${ }^{117}$ As Miguel Centeno and Patricio Silva have remarked, in some cases, democratic regimes have been usurped by "technocratic democracies" where elected representatives have "nominal control" but the "framing of policy alternatives is largely in the hands of experts". 118 In some extreme cases, unelected leaders have been appointed to head executive governments to stabilise the country during a crisis. Most recently, in Greece, economist Lucas Papademos led a Provisional Government from 11 November 2011 to 17 May 2012; in Italy, economist Mario Monti served as Prime Minister from 16 November 2011 to 21 December 2012.

Technocracy is discernible in other areas. Ran Hirschl, among others, has identified a global trend towards "judicialisation of politics", whereby contentious public policy issues and core moral predicaments are increasingly transferred from representative institutions to judiciaries. ${ }^{119}$ While this shift is complex and multifaceted, a "widely-held"120 thesis attributes it to a growing desire to legally protect minority groups from 'majority tyranny' via constitutionalism, bills of rights and muscular judicial review. In this reading, the judiciary, and not the parliament or the people themselves, is the "appropriate fora" for making key decisions because it is more impartial and reputable. ${ }^{121}$ In some respects, empirical evidence supports these claims. Even in Australia, a state without a Bill of Rights, proponents can point to celebrated judicial decisions restraining majority domination, ${ }^{122}$ or righting a historical wrong long-avoided by elected representatives. ${ }^{123}$ Nevertheless, many scholars remain unconvinced; ${ }^{124}$ the judiciary can be as unreceptive to minority claims as any legislature. ${ }^{125}$

Judgments about impartiality and honesty are central for advocates of technocracy, who elevate 'reason' as the primary basis for authority, and seek to redefine moral or political

\footnotetext{
${ }^{116}$ C. Walsh, 'Central Bank Independence' in S. Durlauf and L. Blume (eds), Monetary Economics (Palgrave, Basingstoke, 2010) p. 21, 21.

${ }^{117}$ E. Dargent, Technocracy and Democracy in Latin America: The Experts Running Government (Cambridge University Press, Cambridge, 2015) p. 4.

${ }^{118}$ M. Centeno and P. Silva, 'The Politics of Expertise in Latin America' in M. Centeno and P. Silva (eds), The Politics of Expertise in Latin America (Palgrave MacMillan, Basingstoke, 1998) p. 1, 11.

${ }^{119}$ R. Hirschl, Towards Juristocracy: The Origins and Consequences of the New Constitutionalism (Harvard University Press, Boston, 2004); R. Hirschl, 'The Judicialization of Politics' in G. Caldeira, R.D. Kelemen and K. Whittington (eds), The Oxford Handbook of Law and Politics (Oxford University Press, New York, 2008) p. 119; C.N. Tate and T. Vallinder (eds), The Global Expansion of Judicial Power (New York University Press, New York, 1995).

${ }^{120}$ R. Hirschl, 'Political Origins of the New Constitutionalism' 11 Indiana Journal of Global Legal Studies (2004) p. 75.

${ }^{121}$ Hirschl, 'The Judicialization of Politics', supra note 119, pp. 120 and 135.

${ }^{122}$ Australian Communist Party v Commonwealth (1951) 83 CLR 1.

${ }^{123}$ Mabo v Queensland (No 2) (1992) 175 CLR 1.

${ }^{124}$ G. Rosenberg, The Hollow Hope: Can Courts Bring About Social Change? (University of Chicago Press, Chicago, 1991); I. Shapiro, 'Tyranny and Democracy: Reflections on Some Recent Literature' 43 Government and Opposition (2008) p. 486; Waldron, supra note 19, p. 219.

${ }^{125}$ In the United States see: Prigg v Pennsylvania, 41 US 539 (1842); Dred Scott v Sanford, 60 US 393 (1857) and Korematsu, 322 US 214 (1944); City of Sherrill v Oneida Indian Nation of New York, 544 US 197.
} 
problems as technical. ${ }^{126}$ But such an approach is ultimately quixotic: not all public policy decisions concerning the political relationship between majority and minority communities are, nor can be made, value free. Rather, policymaking must be political; it must be legitimised by popular support. ${ }^{127}$ This central fact of political life derails technocracy as an approach for mediating the relationship between majoritarian democracy and marginalised groups, but it also disrupts more moderate technocratic approaches that acknowledge the existence of ethical value judgments, but, by seeking consensus within an epistemic community, still strive to transmute such judgments into objective, factual pronouncements. ${ }^{128}$ For, as a democrat might inquire: who is this epistemic community?

Indeed, this question raises a further problem with technocracy generally: the notion that technocratic experts do not have their own interests. As Martin Shapiro has explained, "the very specialisation of knowledge required" to become an expert, "render[s] them nonrepresentative of the demos as a whole". ${ }^{129}$ It is likely then, that 'value-free' technocratic standards may distribute scarce benefits unevenly across interest groups. Where this distribution is not grounded in popular support, or cannot be effectively challenged by those disadvantaged, collective self-rule is inhibited. This risk is intensified in circumstances where an epistemic community is composed of an ethno-cultural majority who cannot comprehend the distinctive concerns raised by an ethno-cultural minority. This problem is particularly pronounced when Indigenous aspirations are marginalised by equality principles situated within human rights acts. ${ }^{130}$ In these cases it seems necessary that the numerically smaller Indigenous community is able to decide the issue for themselves.

\subsubsection{Federalism}

Federalism is a system of government that combines both "shared rule and self-rule", ${ }^{131}$ by dividing powers between two or more constituent entities, described as states, provinces, or regions, and a central government. It is often adopted by countries with a large territorially, linguistically or ethnically fragmented population, or as a result of a "federal bargain" between historically sovereign political communities. ${ }^{132}$ Federalism takes various institutional forms, dependent on the precise distribution of powers between its constituent members, and offers real benefits for numerically small marginalised ascriptive communities. In particular, it does not merely offer such groups an opportunity to be heard in the processes of government, but an opportunity to be the government.

\footnotetext{
${ }^{126}$ C. Ribbhagen, Technocracy within Representative Democracy: Technocratic Reasoning and Justification among Bureaucrats and Politicians (Göteborg Studies in Politics, Gothenburg, 2013) p. 23.

${ }^{127}$ K.S. Rahman, Democracy against Domination (Oxford University Press, New York, 2017); A. Binder, 'Is Government too Political?' 76 Foreign Affairs (1997) p. 115. Cf. J. Hibbing and E. Theiss-Morse, Stealth Democracy: Americans' Beliefs about how Government should work (Cambridge University Press, Cambridge, 2002) p. 156 finding that democratic legitimacy of public policy decisions is perhaps not greatly treasured by ordinary citizens.

${ }^{128}$ P. Haas, 'Introduction: Epistemic Communities and International Policy Coordination' 46 International Organisation (1992) p. 3. Though note that this does not mean that technocratic elements are not useful nor desirable in some domains.

${ }^{129}$ M. Shapiro, "Deliberative," "Independent" Technocracy v. Democratic Politics: Will the Globe Echo the EU?' 68 Law and Contemporary Problems (2005) p. 343.

${ }^{130}$ New Zealand: Te Weehi v Regional Fisheries Officer [1986] 1 NZLR 682; Canada: Lovelace v Canada (HRC, 1981); United States: Santa Clara Pueblo v Martinez 436 US 49 (1978); Australia: Maloney v The Queen (2013) 252 CLR 168. See further B. Kingsbury, 'Reconciling Five Competing Conceptual Structures of Indigenous Peoples' Claims in International and Comparative law' 34 New York University Journal of International Law and Politics (2001) p. 189.

${ }^{131}$ R. Watts, 'Federalism, Federal Political Systems, and Federations' 1 Annual Review of Political Science (1998) p. 120.

${ }^{132}$ W. Riker, Federalism: Origin, Operation, Significance (Little Brown, Boston, 1964) pp. 11-14.
} 
Federalism is inherently "demos-constraining" as it divides competencies between the constituent entities. ${ }^{133}$ This institutional form protects individuals from abuse by the majority, and enables members within the substate community to have their interests heard in the central government's decision-making body. Section 7 of the Australian Constitution, for instance, guarantees "equal representation" of each state, regardless of population size, ensuring that the interests of Tasmanians are heard in the processes of government, notwithstanding their small population. Nonetheless, while federalism operates as an institutional constraint to undifferentiated majority rule, its most significant element is that it enables individuals, communities and peoples to find political expression in multiple manifestations. ${ }^{134}$ Just as this aspect enhances the opportunity for Tasmanians to involve themselves in political decision-making, it has the potential to accommodate numerical minorities who consider themselves national groups and wish to preserve their identity.

Liberal political theorists are increasingly receptive to the distinctiveness of ethno-cultural minorities, and accept that in some instances a form of partial veto power, achieved via federalism, may be appropriate. This shift first occurred in the early 1990s, as scholars acknowledged that the liberal democratic state's claim of ethno-cultural neutrality is a "myth", ${ }^{135}$ noting that public policy decisions relating to, for example, language and civic holidays, are not value free, but reflect attitudes of the dominant cultural group. ${ }^{136}$ Drawing on the significance of identity and membership, Yael Tamir and, Will Kymlicka, among others, argued that the state should respect the wishes of ethno-cultural minorities to preserve their identity and culture, because such membership is an important and constitutive element of personal identity. ${ }^{137}$ A person's "societal culture" provides a complete context of choice, "determin[ing] the boundaries of the imaginable,"138 and offering a range of meaningful options "across the full range of human activities, including social, educational, religious, recreational, and economic life, encompassing both public and private spheres". ${ }^{139}$ As a result of the "disintegrating effects" 140 of the choices of the dominant cultural community, the state should ensure that minority societal cultures are protected. ${ }^{141}$

Disagreement arises, however, over the form that legal and political institutions and processes to protect ethno-cultural minorities, should take. Tamir argues in favour of regional organisations, local autonomies and consociationalism, ${ }^{142}$ a form of corporatism along social, ethnic, or religious lines, ${ }^{143}$ while Kymlicka draws a distinction between Indigenous peoples

\footnotetext{
${ }^{133}$ A. Stepan, 'Federalism and Democracy: Beyond the U.S. Model' 10 Journal of Democracy (1999) p. 23.

${ }^{134}$ R. Whitaker, 'Federalism and Democratic Theory' (Institute of Intergovernmental Relations, Queen's University, Discussion Paper No. 17, 1983) p. 2.

${ }^{135}$ W. Kymlicka, 'Western Political Theory and Ethnic Relations in Eastern Europe' in W. Kymlicka and M. Opalski (eds), Can Liberal Pluralism be Exported? Western Political Theory and Ethnic Relations in Eastern Europe (Oxford University Press, New York, 2002) p. 13, 16; Y. Tamir, Liberal Nationalism (Princeton University Press, Princeton, 1993) p. 146.

136 Tamir, supra note 135 , p. 54; Kymlicka, supra note 86.

137 Tamir, supra note 135 , pp. 35-7.

138 A. Margalit and J. Raz, 'National Self-Determination' 87 The Journal of Philosophy (1990) p. 449.

${ }^{139}$ Kymlicka, supra note 86, p. 76.

${ }^{140}$ W. Kymlicka, Liberalism, Community and Culture (Oxford University Press, New York, 1989) p. 198.

${ }^{141}$ Kymlicka, supra note 86, p. 110.

142 Tamir, supra note 135 , pp. 152-4.

${ }^{143}$ See A. Lijphart, Democracy in Plural Societies: A Comparative Exploration (Yale University Press, New Haven, 1977); A. Lijphart, 'Constitutional Design for Divided Societies' 15 Journal of Democracy (2004) p. 96. Cf. C. Jung and I. Shapiro, 'South Africa's Negotiated Transition: Democracy, Opposition, and the New Constitutional Order' 23 Politics \& Society (1995) p. 269. Consociationalism requires a balance of power
} 
and other ethno-cultural minorities. For Kymlicka, Indigenous peoples are entitled to selfgovernment rights, whereas other minorities are granted a more limited set of polyethnic rights, which are "intended to promote integration into the larger society, not selfgovernment". ${ }^{144}$ More recently, Siobhan Harty and Michael Murphy draw on these liberal nationalist scholars, but shy away from grounding self-determination in cultural distinctiveness, instead emphasising its connection to democracy and a people's "democratic right to be self-governing". ${ }^{145}$ A similar approach is taken by Steven Curry who grounds the legitimacy of government on popular sovereignty. ${ }^{146}$

These approaches appear positive, but are they limited to territorially-concentrated ethnocultural numerical minorities? Not necessarily. Federalism divides competencies between different entities that share the same territorial space, but there is no need-as the Ottoman millet system evidences - to define the constitutive entities on the basis of geography. ${ }^{147}$ In the 1890s, Austro-Hungarian scholar Karl Renner proposed grounding autonomy on personality not territoriality. ${ }^{148}$ Like contemporary liberal nationalists, Renner's approach distinguishes between the state as "a sovereign territorial entity", and a nation as "a cultural community". ${ }^{149}$ As Ephraim Nimni explains, the idea behind Renner's model was to enable autonomous ethno-cultural communities to organise "as sovereign collectives whatever their residential location within a multinational state." 150 In contrast to the Ottoman approach, however, under Renner's model, the autonomous communities would be based on individual consent. ${ }^{151}$

Diana Meyers' solution also avoids the territorial problem while paying attention to the particular values and aspirations of ethno-cultural minorities. Conscious of the risk untrammelled democracy poses to these groups, Meyers would qualify majority rule on issues that "are integral to [a person's] individual identities... as well as personal or moral positions that are anathema to them", but permit majority rule to decide questions that affect a person's "annexed" qualities, that is "personal commitments and moral beliefs that are peripheral, but not alien to [a person's] individual identities". ${ }^{152}$ Though Meyers' account is intended to defend counter-majoritarian principles, her approach is only feasible in a situation characterised by general societal agreement on a hierarchy of values, and it is not at all clear how this position can be institutionalised where the very dispute concerns the centrality of a person's values. Does the French state's commitment to secularism allow a majoritarian

\footnotetext{
between groups and so is unlikely to be effective in cases of numerical minorities. As such, it is not a focus of this paper.

${ }^{144}$ Kymlicka, supra note 86, pp. 30-31.

${ }^{145}$ S. Harty and M. Murphy, In Defence of Multinational Citizenship (University of British Columbia Press, Vancouver, 2005) p. 79. While Harty and Murphy do not offer any indicia over whether an ethno-cultural minority constitutes a 'people', Tamir would grant that status to any group that exhibits a 'sufficient number' of shared objective characteristics, such as language and culture, and self-awareness of its distinctiveness: Tamir, supra note 135 , pp. 65-67.

${ }^{146}$ S. Curry, Indigenous Sovereignty and the Democratic Project (Ashgate, Aldershot, 2004) pp. 16-17.

${ }^{147}$ See e.g. K. Barkey and G. Gavrilis, 'The Ottoman Millet System: Non-Territorial Autonomy and its Contemporary Legacy’ 15 Ethnopolitics (2016) p. 24.

${ }^{148}$ K. Renner, 'State and Nation' (1889) in E. Nimni, (ed), National-cultural Autonomy and Its Contemporary Critics (Routledge, London, 2005) p. 15.

${ }^{149}$ Ibid., pp. 24-25.

${ }^{150}$ E. Nimni 'Introduction: The National Cultural Autonomy Model Revisited' in E. Nimni, (ed), Nationalcultural Autonomy and Its Contemporary Critics (Routledge, London, 2005) p. 1, 10.

${ }^{151}$ Renner, supra note 148, p. 20.

${ }^{152}$ D. Meyers, 'Democratic Theory and the Democratic Agent' in J. Chapman and A. Wertheimer (eds), Majorities and Minorities: Nomos XXXII (New York University Press, New York, 1990) p. 126, 139.
} 
parliament to ban distinctive items of dress worn by religious minorities? ${ }^{153}$ Is the decision to wear a burqa integral to a person's identity, or merely a peripheral personal commitment? Meyers' approach does not provide any answers to these questions.

This same flaw is present in Dirk Jorke's recent proposal to grant temporary veto power over certain legislation to socially disadvantaged groups. Concerned that the interests of economically marginalised groups are not heard in government, Jorke suggests that on "extremely" controversial acts "which aim to reshape the social structure of the society", socially disadvantaged individuals should be permitted a chance to veto the legislation via an optional referendum. This veto power is highly circumscribed, however, as it merely postpones the implementation of the act to permit parliament to consider the decision anew. ${ }^{154}$ Jorke conceives this device as ensuring that members of less-privileged groups "are heard to a larger extent than at present, but not necessarily to grant them more influence than others". ${ }^{155}$ In this, Jorke avoids Pettit's general critique of partial veto power mechanisms, as the socially disadvantaged are not entitled to negate public decisions, but merely to call them into question by triggering renewed debate. ${ }^{156}$ But, who should decide when an Act "aims to reshape the social structure of the society"? Jorke's solution is unpersuasive; simple majority vote by an additional deliberative body, chosen by lot from the socially disadvantaged, would result in a referendum. ${ }^{157}$ The problems in Meyers and Jorke's proposals appear to be inherent to models of jurisdiction sharing: is there an alternative approach that allows ethno-cultural minorities to be heard (or even to decide for themselves) notwithstanding their demographic size?

\subsection{Extending Democracy beyond Aggregation}

Recognition that an equal opportunity to participate in the political process does not necessarily permit ethno-cultural minorities to shape their society by affecting law and policy under a system of majority rule, has led some democratic theorists to focus on shifting understandings about collective self-rule away from the aggregation of votes. ${ }^{158}$ Under aggregative decision-making systems, numerical minorities that constitute ascriptive marginalised groups will very likely become persistent electoral minorities, weakening both the legitimacy of the state and democracy's commitment to self-rule. This understanding informs much of the "deliberative turn" in democratic theory, ${ }^{159}$ a more inclusive model that seeks to justify decisions primarily "on the sharing of reasons", ${ }^{160}$ as well as Philip Pettit's neo-republican model of freedom as non-domination. ${ }^{161}$ Each will be explored in turn.

\footnotetext{
153 S.A.S. v France [2014] ECHR 695.

${ }^{154}$ D. Jorke, 'Political Participation, Social Inequalities, and Special Veto Powers' 19 Critical Review of International Social and Political Philosophy (2016) pp. 331-2.

155 Ibid., p. 332.

${ }^{156}$ Pettit, supra note 53, p. 180.

157 Jorke, supra note 154 , pp. 330-2.

${ }^{158}$ See e.g. S. Chambers, 'Deliberative Democratic Theory' 6 Annual Review of Political Science (2003) p. 307.

Some scholars working within this approach advocate sortition as a mechanism to avoid the danger that economic or political inequalities will condition electoral success. See e.g. Van Reybrouck, supra note 79; McCormick, supra note 79; B. Manin, The Principles of Representative Government (Cambridge University Press, Cambridge, 1997).

${ }^{159}$ J. Dryzek, Deliberative Democracy and Beyond: Liberals, Critics, Contestations (Oxford University Press, New York, 2002) p. 1.

${ }^{160}$ S. Wheatley, 'Deliberative Democracy and Minorities' 14 European Journal of International Law (2003) p. 510.

${ }^{161}$ Pettit, supra note 106; Pettit, supra note 32; Pettit, supra note 53.
} 


\subsubsection{Deliberative Democracy}

Central to deliberative democracy is the notion of equality. For Iris Marion Young, equality is a substantive requirement, primarily referring to the "full participation and inclusion" of all citizens in "society's major institutions". 162 This open, participatory ethic flows from deliberative democrats' view that the legitimacy of a decision depends not on an aggregation of votes, but "on the degree to which those affected by it have been included in the decisionmaking processes and have had the opportunity to influence the outcomes." "163 An inclusive process of decision-making is predicated on a deliberation structured around "a free public reasoning among equals", ${ }^{164}$ who advance their positions by "impartial"165 "appeal to the common will", ${ }^{166}$ in a process intended to encourage otherwise marginalised voices to speak and be heard. Such a process has broadly expressive and symbolic goals in positioning each person as an equal deserving of respect, but also has epistemic justification in enlarging the pool of ideas with diverse perspectives, jettisoning poor arguments and building a consensus on the best solution. ${ }^{167}$ Even if consensus is not reached, deliberative democratic theorists contend that it leads to greater respect among participants. ${ }^{168}$

In structuring deliberation around appeals to the common will, participants can defend their understanding or interpretation of the common good, but must do so only using norms "which all possibly affected persons could agree as participants in rational discourses". ${ }^{169}$ While this has an educative and moralistic function, in shaping citizens' interests and identity towards the common good, ${ }^{170}$ its broader purpose is in creating an environment based on public reason and equality. Permitting persons to justify their arguments on premises over which essential disagreement exists would weaken the inclusive, deliberative process, denying its dialogical promise and potentially opening it up to abuse by demagogues. ${ }^{171}$ True to deliberative democrats' strong understanding of equality, the state must create social conditions to develop each citizen's capacities so that all have an equal capability to influence decisions, ${ }^{172}$ and

\footnotetext{
162 Young, supra note 86, p. 173

${ }^{163}$ Young, supra note 88, pp. 5-6, 52. See also B. Manin, 'On Legitimacy and Political Deliberation' 15 Political Theory (1987) p. 352; M. Williams, 'The Uneasy Alliance of Group Representation and Deliberative

Democracy' in W. Kymlicka and W. Norman (eds), Citizenship in Diverse Societies (Oxford University Press, New York, 2000) p. 124, 128.

${ }^{164}$ J. Cohen 'Procedure and Substance in Deliberative Democracy' in S. Benhabib (ed), Democracy and Difference (Princeton University Press, Princeton, 1996) p. 95, 99.

${ }^{165}$ S. Benhabib, 'Toward a Deliberative Model of Democratic Legitimacy' in S. Benhabib (ed), Democracy and Difference (Princeton University Press, Princeton, 1996) p. 67, 83.

166 J. Elster, 'The Market and the Forum: Three Varieties of Political Theory' in J. Bohman and W. Rehg (eds), Deliberative Democracy: Essays on Reason and Politics (Massachusetts Institute of Technology Press, Cambridge, 1998) p. 3, 12.

${ }^{167}$ Landemore, supra note 46, p. 97; Young, supra note 88, pp. 30-31.

168 A. Gutmann and D. Thompson, Democracy and Disagreement (Princeton University Press, Princeton, 1996) p. 9

${ }^{169}$ J. Habermas, Between Facts and Norms: Contributions to a Discourse Theory of Law and Democracy (Massachusetts Institute of Technology Press, Cambridge, 1996) p. 107.

${ }^{170}$ J. Cohen, 'Deliberation and Democratic Legitimacy' in R. Goodin and P. Pettit (eds), Contemporary Political Philosophy (Wiley-Blackwell, Oxford, 2006) p. 159, 163.

${ }^{171}$ S. Chambers, 'Rhetoric and the Public Sphere: Has Deliberative Democracy Abandoned Mass Democracy?' 37 Political Theory (2009) p. 324. Note that Chambers distinguishes between 'plebiscitary' and 'deliberative' rhetoric: p. 355.

${ }^{172}$ J. Knight and J. Johnson, 'What Sort of Political Equality Does Deliberative Democracy Require?' in J. Bohman and W. Rehg (eds), Deliberative Democracy: Essays on Reason and Politics (Massachusetts Institute of Technology Press, Cambridge, 1997) p. 279; Young, supra note 86, p. 173. I take this to mean that the state seeks to ensure that all citizens are capable of communicating in dispassionate and rational terms, cf. L. Sanders, 'Against Deliberation' 25 Political Theory (1997) p. 348. Duncan Ivison envisages a postcolonial liberal order in similar terms: D. Ivison, Postcolonial Liberalism (Cambridge University Press, Cambridge, 2002) p. 133.
} 
must ensure that unequal distributions of power and resources do not shape contributions during the deliberative process. ${ }^{173}$ The only force that is supposed to coerce individuals is "the force of the better argument". ${ }^{174}$

The fundamental features of the deliberative model (public equality, participation, inclusion and consensus) are attractive to ethno-cultural minorities, including Indigenous peoples. ${ }^{175} \mathrm{In}$ reconceptualising democracy away from the aggregation of votes, the fact that these groups constitute a numerical minority is not necessarily determinative of the eventual decision. Second, in providing a space for all citizens to speak based on conditions of equality and reciprocity, deliberative democracy promises enhanced access to decision-making forums. Finally, in emphasising decisions based on public reason (informed by the participants' unique perspectives), marginalised ascriptive groups may legitimately hope that a broader understanding of the common good, one that incorporates all (rather than merely a majority of) participants' aspirations and demands, will prevail.

Nonetheless, concerns surround both problematic assumptions underlying deliberative democracy and difficulties in securing truly deliberative processes in practice, limiting the benefit that it offers for marginalised ascriptive groups. The chief concern identified by difference theorists is the requirement that deliberation be structured around public reasoning based on appeals to the common good. This requirement privileges forms of reasoning not necessarily characteristic of ethno-cultural minorities, denying them the opportunity to utilize forms of communication they consider more appropriate, including rhetorical devices such as storytelling, or disruptive or disorderly actions. ${ }^{176}$ Although positioned as neutral then, deliberative democracy appears to force marginalised groups to enter the process on the terms of the dominant community. Young's solution to this problem involves greater awareness of and attention to the disadvantages faced by marginalised groups within the "fair, open and inclusive democratic processes", ${ }^{177}$ but it is not clear what this entails in practice. Does it involve greater opportunity for such groups to speak? Or allowance for Indigenous peoples, for example, to communicate in a manner they consider more appropriate? ${ }^{178}$

Increasing the opportunity for marginalised groups to speak would involve diminishing deliberative democracy's commitment to public equality as it would necessarily reduce time for others. The second option, however, appears beneficial, as it recognises that Indigenous peoples, for example, are differently situated and consequently structures the deliberative process in a way that encourages their continued participation. When combined with a commitment to listening on behalf of members of the dominant culture, ${ }^{179}$ recognising that diverse communicative strategies may satisfy the standard of 'reasonableness' accords with deliberative democracy's ideals of inclusion and equality. ${ }^{180}$ And yet, this move unveils what

\footnotetext{
173 J. Cohen, 'Economic Bases of Deliberative Democracy' 6 Social Philosophy \& Policy (1989) p. 33.

${ }^{174}$ Habermas, supra note 169, p. 108; J. Black, 'Proceduralizing Regulation: Part 1' 20 Oxford Journal of Legal Studies (2000) p. 609.

175 Wheatley, supra note 160, p. 508; A. Connolly, 'Introduction' in A. Connolly (ed) Indigenous Rights (Ashgate, Aldershot, 2009) p. xxxii.

${ }^{176}$ I.M. Young, 'Communication and the Other: Beyond Deliberative Democracy' in S. Benhabib (ed) Democracy and Difference (Princeton University Press, Princeton, 1996) p. 120, 123; Young, supra note 88, p. 49; J. Boswell, 'Why and How Narrative Matters in Deliberative Systems' 61 Political Studies (2013) p. 623.

177 Young, supra note 88, pp. 50, 119.

${ }^{178}$ See Dryzek, supra note 159, pp. 71-72.

${ }^{179}$ A. Dobson, Listening for Democracy: Recognition, Representation, Reconciliation (Oxford University Press, New York, 2014) p. 114.

${ }^{180}$ Dryzek would allow rhetoric and diverse communicative strategies provided that it 'contributes to the construction of an effective deliberative system joining competent and reflective actors on the issue at hand': J.
} 
Melissa Williams refers to as the "contingency" of the "standard of reasonableness that lies at the heart of deliberative theory", ${ }^{181}$ potentially derailing the entire process. A significant cause of disagreement between members of ethno-cultural minorities and members of the dominant culture centres on the judgment that particular arguments are reasonable or not. In the case of Indigenous peoples, this disagreement can be even starker. Many non-Indigenous Australians have difficulty conceptualising Indigenous Australians' relationship to country and its role as the basis of cultural, spiritual and personal identity. In these circumstances, non-Indigenous Australians may consider that the traumatic consequences, including "loss of personal identity" Indigenous Australians feel when dispossessed, ${ }^{182}$ is 'unreasonable'. Their views will not be taken seriously. Even putting to one side the likelihood that background inequalities will condition or skew the deliberative process, ${ }^{183}$ if this psychological gap cannot be bridged, it is difficult to see what deliberative democracy offers Indigenous peoples.

One way out of this challenge might be to redefine the goals of deliberative democracy. More recent deliberative democrats have recognised that some forms of consensus will not, and need not, always be achieved. ${ }^{184}$ John Dryzek draws a typology of consensus to differentiate between consensus and meta-consensus. While normative consensus, for example, concerns agreement on the values that should predominate within a deliberation, normative metaconsensus seeks mutual recognition of the legitimacy of the disputed values, without necessarily stretching to an agreement on which of the disputed values should receive priority. ${ }^{185}$ Drawing on psychological literature that suggests there is a high degree of agreement on the legitimacy of basic values, ${ }^{186}$ Dryzek argues that appropriately structured deliberative democracy may uncover agreement at the normative meta-consensus level. In terms of disputes over land and natural resources between Indigenous and non-Indigenous peoples, it is likely that participants on both sides will recognise that such disputes need not be positioned in a zero-sum game. Dryzek's normative meta-consensus “implies reciprocal understanding and recognition of the legitimacy of the values held by other participants in political interaction". ${ }^{187}$

Significantly, empirical studies suggest that with careful attention to structural dynamics, deliberative democracy can be effective in mediating the relationship between Indigenous and non-Indigenous peoples. James Fishkin describes a deliberative poll conducted in 2001 on issues concerning Indigenous Australians. Recognising the demographic problem, the poll oversampled Aboriginal and Torres Strait Islander peoples, selecting 46 persons in addition to 344 non-Indigenous Australians, randomly assigned to small groups of 10 to 25. Results indicate that deliberation greatly improved non-Indigenous Australians understanding of Indigenous concerns and support for Indigenous aspirations. ${ }^{188}$ This is positive and points to

Dryzek, Foundations and Frontiers of Deliberative Governance (Oxford University Press, New York, 2010) p. 84.

${ }^{181}$ Williams, supra note 163, p. 137. See also I. Shapiro, 'On Non-Domination' 62 University of Toronto Law Journal (2012) pp. 312-313 critiquing Habermas’ position for requiring rationality.

182 R.P. Hill, 'Blackfellas and Whitefellas: Aboriginal Land Rights, the Mabo Decision, and the Meaning of Land' 17 Human Rights Quarterly (1995) pp. 310, 313-17.

${ }^{183}$ Williams, supra note 163, p. 137. See further Phillips, supra note 96, p. 154.

${ }^{184}$ Dryzek, supra note 180, p. 85; Cf. Habermas, supra note 169, p. 110.

${ }^{185}$ Dryzek, supra note 180, pp. 93-100.

${ }^{186}$ Ibid., p. 97.

${ }^{187}$ Ibid., p. 102.

188 J. Fishkin, When the People Speak: Deliberative Democracy and Public Consultation (Oxford University Press, New York, 2011) pp. 161-3. 
the real possibilities of deliberative democracy in fomenting a style of public reasoning that is more receptive and sensitive to Indigenous peoples.

The focus on reciprocity and dialogue are key elements in an effective deliberative democracy. Nevertheless, a number of questions surrounding feasibility remain. In particular, in light of the fact that political institutions generally remain far from the deliberative ideal, what institutions and processes are required to transform Fishkin's "mini publics" into mass publics? ${ }^{189}$ And are institutions sufficient, or will broader cultural change be required? If so, how can this be accomplished?

\subsubsection{Institutionalising Contestation}

Elections may be the primary means of ensuring government is accountable to citizens, "but they are very unlikely to be sufficient", ${ }^{190}$ as they fail to ensure that government action is directed by all citizens. Indeed, "Electoral fundamentalis[m]"191 offers little for ascriptive marginalised groups, as "it is difficult for minorities to register their dislike for government policy at the ballot box because it has no impact, and the majority do not have any selfinterest in the concerns of any particular minority". ${ }^{192}$ Recognition of this fact has led some democratic theorists to delineate two modes in the representative relationship: identifying an election mode and a between-election mode. ${ }^{193}$ If persistent electoral minorities cannot succeed in influencing government action via the election mode, then mechanisms and processes that channel popular will, provide opportunities for political contestation, and promote interaction between the represented and the representatives should be devised for the between-election mode. This tradition is similar but distinct to technocratic democratic arrangements. Rather than excise issues to managerial bodies, decisions are still made via majoritarian institutions, but citizens are granted greater opportunity to contest those decisions, and have their voices heard.

Robert Dahl is one theorist who understood the significance of contestation and non-electoral mechanisms for democratic theory. Dahl conceived of democracy as requiring "continuing responsiveness" by the government "to the preferences of its citizens, considered as political equals". ${ }^{194}$ This shifts our view from irregular election dates to institutions and processes feeding interests and views back to government throughout the electoral cycle. This understanding is also present in Ian Shapiro's account of democracy as the "structured competition for power". ${ }^{195}$ For Shapiro, democracy works only when it is competitive because bipartisan politics masks domination. ${ }^{196}$ The privileging of thin accounts of democracy that equate it primarily to electoral control runs the risk of failing to recognise domination. In an excoriating essay lamenting the absence of Indigenous voices in policy making and public life in Australia, Megan Davis draws on Shapiro:

\footnotetext{
${ }^{189}$ Fishkin, supra note 188, pp. 168-9; S. Niemeyer, 'Scaling Up Deliberation to Mass Publics: Harnessing Mini-Publics in a Deliberative System' in K. Gronlund, A. Bachtiger and M. Setala (eds), Deliberative MiniPublics: Involving Citizens in the Democratic Process (European Consortium for Political Research Press, Wivenhoe Park, 2014) p. 177.

190 Pettit, supra note 32, p. 304.

191 Van Reybrouck, supra note 79, p. 39.

192 Davis, 'The United Nations Declaration on the Rights of Indigenous Peoples', supra note 93, p. 7.

${ }^{193}$ See e.g. P. Esaiasson and H.M. Narud (eds), Between-Election Democracy: The Representative Relationship after Election Day (European Consortium for Political Research Press, Wivenhoe Park, 2013).

${ }^{194}$ R. Dahl, Polyarchy: Participation and Opposition (Yale University Press, New Haven, 1971) 1 (emphasis added).

195 Shapiro, supra note 61, p. 148.

196 Ibid., p. 149.
} 
For Indigenous Australians the system is broken. When self-determination was abandoned it was replaced by a seemingly benign, upbeat and eternally cooperative bipartisanship. But bipartisanship is deceptively simple. Intuitively it makes sense, but it does not always sit well in a parliamentary liberal democracy whose institutions are based on the mediation of disagreement. And when a policy area involves 2 per cent of twenty-three million people, it becomes a significant problem for the scrutiny of decisions between the ballot box..$^{197}$

Davis highlights the key element in a system of continuing responsiveness - scrutiny between the ballot box. Philip Pettit's republican theory of government adopts a similar approach, though, rather than focusing on 'responsiveness', Pettit links freedom (and democracy) to non-domination and 'contestation'. For Pettit, a government is democratic to the extent that "the people individually and collectively enjoy a permanent possibility of contesting"198 government decisions. The problem posed by persistent electoral minorities, or "sticky minorities", as Pettit terms them, is that their members will not have an equal chance at influence under electoral mechanisms. ${ }^{199}$

The solution is to establish impartial institutions that "promise to give people a power of contesting what government does that parallels their collective power to determine who shall be in government". ${ }^{200}$ But ensuring that every action of government is able to "be effectively contestable by those affected", ${ }^{201}$ requires certain institutional structures, including: a potential basis for contestation; a channel available by which decisions may be contested; and a suitable forum for hearing contestations. ${ }^{202}$ The inclusive republic that Pettit envisages provides both a formal entitlement to individuals and groups to "speak out against" government policy, and a substantive guarantee that such groups can speak out in a way that is "liable to affect...proposed legislation". ${ }^{203}$

These contestatory structures operate at two levels. At the individual and collective level, Pettit envisages citizens as "resistance prone". ${ }^{204}$ This places stringent demands on citizens, requiring them to take an active participation in civic and political life, ${ }^{205}$ and to remain vigilant in publicising and protecting their and others interests. ${ }^{206}$ The forum for contestation will include various processes, such as ombudsman, inquiries, and courts, enabling citizens to challenge governmental decisions and policies. But these bodies will only be effective if the government is "resistance-averse", ${ }^{207}$ meaning it respects the process and funds the

\footnotetext{
197 Davis, 'Listening but not Hearing', supra note 93, pp. 84-85.

${ }^{198}$ Pettit, supra note 106, p. 185.

${ }^{199}$ Pettit, supra note 32, p. 212.

${ }^{200}$ P. Pettit, 'Minority Claims under Two Conceptions of Democracy' in D. Ivison, P. Patton and W. Sanders (eds), Political Theory and the Rights of Indigenous Peoples (Cambridge University Press, Cambrdige, 2000) p. 199, 209. Pettit, supra note 32, p. 213.

${ }^{201}$ Pettit, supra note 106 , p. 172

202 Pettit, supra note 106, pp. 186-200. See also Pettit, supra note 32, p. 208; Pettit, Just Freedom: A Moral Compass for a Complex World (W. W. Norton \& Company, New York, 2014) p. 125.

${ }^{203}$ Pettit, supra note 106, p. 190. Pettit does not go so far as to offer groups veto power.

${ }^{204}$ Pettit, supra note 32, p. 174.

${ }^{205}$ H. Haugen, 'Participation and Decision-Making in Non-Dominant Communities: A Perspective from Civic Republicanism' 23 International Journal on Minority and Group Rights (2016) p. 310.

206 A. Peterson, Civic Republicanism and Civic Education: The Education of Citizens (Palgrave MacMillan, Basingstoke, 2011) p. 105; Shapiro, supra note 181, pp. 325-6.

${ }^{207}$ Pettit, supra note 32, p. 174.
} 
institutions accordingly. For Pettit, this extends the substantive right to contest beyond external interventions such as protests, petitions or claims, and includes equitable representation within the legislature, bureaucracy and judiciary. ${ }^{208}$ While the question of proportional representation and reserved seats will be addressed in detail in Part III.C, it is clear that this reform offers marginalised ascriptive groups a real opportunity to challenge government as well as influence legislation and policy. ${ }^{209}$

This is not to say, however, that Pettit's vision does not also contain troubling elements. John McCormick avers that Pettit's institutions are too weak, arguing that contestation does not provide real accountability and therefore fails to ensure an effective voice for minority groups. ${ }^{210}$ Conversely, even if the proliferation of institutions promoting contestation prevents majority domination, it also tends to sclerotize decision-making, which will likely privilege the status quo, preventing changes to benefit minority groups. ${ }^{211}$ Second, and perhaps more problematically, institutional structures that provide a forum for contestation are one thing, but to be effective they require individuals to utilise them. For marginalised individuals, seeking review of a government decision can entail significant burdens. ${ }^{212}$ It is unrealistic to expect such groups take on Pettit's Herculean role, securing their freedom from domination by contesting each and every administrative action.

While Pettit anticipates that his ideal citizenry may be regarded as overly optimistic, and acknowledges that a more "plausible means" to monitor and control government is required, ${ }^{213}$ his solution, which shares commonalities with deliberative democracy, ${ }^{214}$ suffers similar difficulties. Pettit argues that republican deliberation should be guided by a norm that participants must base their arguments on considerations "all can regard as relevant". ${ }^{215}$ Of course, disagreement will likely "always remain in place", and it is, therefore, necessary at some point to achieve resolution by voting, ${ }^{216}$ but, so long as participants interact in this manner, the shared policy-making norms (e.g. equality, respect) will influence and shape candidate policies over the long term. Unsurprisingly, this approach has been criticised as idealistic. $^{217}$

Nonetheless, Pettit's republican focus on freedom as non-domination, rather than noninterference, is useful for thinking about the problem of ascriptive marginalised groups who are in a non-dominant position relative to the majority society and its agencies. Although the majority community may never interfere, its capacity to do so, suggests that the minority are not truly free. Pettit encourages thinking critically about developing institutions, processes, and mechanisms that provide opportunities for ethno-cultural minorities to contest government action, but does so in a way that does not impose unrealistic burdens on them. As

\footnotetext{
${ }^{208}$ Pettit, supra note 106, p. 191: 'the reliably inclusive legislature will have to incorporate...all the voices of difference that are found within the community'. McCormick, supra note 79, p. 153.

${ }^{209}$ Note McCormick critiques Pettit for focusing primarily on ethno-cultural minorities and ignoring 'the principle asymmetry of power, that of wealthy citizens over poorer citizens': McCormick, supra note 79, p. 154. As explained above, McCormick's focus elides pertinent distinctions with 'the people'.

${ }^{210}$ Ibid., pp. 155-160

${ }^{211}$ Shapiro, supra note 181, pp. 329, 331; Dyzenhaus, supra note 80, pp. 341-2.

${ }^{212}$ See e.g. Commonwealth of Australia, Australian Law Reform Commission, Equality, Capacity and Disability in Commonwealth Laws, Discussion Paper No 81 (2014) Chapter 7.

${ }^{213}$ Pettit, supra note 32, p. 251.

214 Ibid., pp. 267-8.

215 Ibid., p. 245.

216 Ibid., p. 257.

${ }^{217}$ Shapiro, supra note 181 , pp. 326-7.
} 
government responsiveness is tied to contestation, ${ }^{218}$ this approach will likely enhance the ability of members of these groups to have their interests reflected in the processes of government, helping to realise democracy's commitment to collective rule.

\subsection{Enhancing the Value of Voting Power}

The previous section examined how democratic theorists have adopted and adapted nonelectoral mechanisms to protect and promote the interests of marginalised ascriptive groups. An alternative approach involves working within electoral mechanisms, but amending the structure and operation of majoritarian democracy, to ensure meaningful access to the "forum where public policy is finally fashioned". ${ }^{219}$ Four related institutional forms will be explored: plural voting, drawing electoral boundaries to enhance the ability of ethno-cultural minorities to elect candidates of their choice, proportional representation, and reserved seats. While each of these methods differs in significant ways, and consequently, their justifications rest on distinct normative grounds, ${ }^{220}$ they are all drawn from the same idea: political decisions are legitimate to the extent that the position of each citizen-including the minority-is considered equally, ${ }^{221}$ and this requires "that they be adequately and effectively represented". ${ }^{222}$ In other words, democracy requires all of the people, not just a majority, to rule collectively.

\subsubsection{Plural Votes}

Concerned about the position of numerical minorities under electoral democracies, some democratic theorists have explored the concept of providing additional votes to minority subgroups within the state. These approaches have generally not been developed to assist marginalised ascriptive groups, but to achieve other important democratic goals, such as more accurately reflecting the intensity of interests at stake, ${ }^{223}$ or realising the putative right to a competent government. ${ }^{224}$ Nonetheless, the logic in some formulations may translate. ${ }^{225}$ Historically, democracy has privileged certain subgroups within a state by restricting suffrage. Plural voting is similar, but conceptually distinct, as advocates generally accept the premise that all citizens should receive a vote, thus agreeing that political decisions are legitimate only if everyone affected has an equal opportunity to participate. ${ }^{226}$ The question, of course, is how many opportunities each person might have.

\footnotetext{
${ }^{218}$ S. Hobolt and R. Klemmensen, 'Government Responsiveness and Political Competition in Comparative Perspective’ 41 Comparative Political Studies (2008) p. 309.

${ }^{219}$ L. Guinier, 'The Representation of Minority Interests: The Question of Single-Member Districts' 14 Cardozo Law Review (1993) p. 1139 citing the United States case Whitcomb v Chavis 403 US 124, 159 (1971) (White J). ${ }^{220}$ As Andrew Rehfeld notes, 'it is only by reference to the function of a representative body that we can think about how its institutions ought to be designed': A. Rehfeld, The Concept of Constituency (Cambridge University Press, Cambridge, 2005) p. 148. Rehfeld discerns 10 distinct normative justifications: 4 rights-based, 6 consequentialist: pp. 47-51.

${ }^{221}$ Urbinati, supra note 52, pp. 41-2.

${ }^{222}$ New Zealand, Royal Commission on the Electoral System, Towards a Better Democracy (1986) p. 88 paragraph 3.27.

${ }^{223}$ P. Moraro, 'Younger citizens should have more votes than those over 60', Sydney Morning Herald, 26 July

2016 <http://www.smh.com.au/ comment/younger-citizens-should-be-allowed-more-votes-than-those-over-60-20160706-gpzq69.html >

${ }^{224}$ J. Brennan, 'The Right to a Competent Electorate' 61 The Philosophical Quarterly (2011) p. 700.

${ }^{225}$ E. Baccarini and V. Ivankovic, 'Mill's Case for Plural Voting and the Need for Balanced Public Decisions' 14 Prolegomena (2015) p. 138. Richard Arneson argues that reserved seats are an institutional system of plural voting but I consider them to be distinct: R. Arneson, 'Democratic Rights at the National Level' in T. Christiano (ed), Philosophy and Democracy: An Anthology (Oxford University Press, New York, 2003) p. 95, 110.

${ }^{226}$ See Brennan, supra note 46 for a defence of epistocracy that is based on a system of restricted suffrage.
} 
John Stuart Mill has provided the most significant justification for plural votes. Mill's argument for plural voting rested on his understanding of the purpose of government. For Mill, "a government is to be judged...by....its tendency to improve or deteriorate the people themselves, and the goodness or badness of the work it performs for them, and by means of them". ${ }^{227}$ Government thus has an educative and protective function. ${ }^{228}$ It must educate its citizens in "intellectual, practical, and moral" 229 senses while serving the interests of the entire community. Mill argued that a plural voting regime that favours educated peoples will produce better outcomes because those receiving additional votes have "greater capacity for the management of the [community's] joint interests". ${ }^{230}$ In contrast, an egalitarian voting system would mean "the great majority of voters...would be manual labourers", and correspondingly, the danger of "class legislation", ${ }^{231}$ by which Mill meant "sinister" and "selfish" partial interests at odds with the common good, ${ }^{232}$ "would still exist in a very perilous degree". ${ }^{233}$ Mill accepted that "it is a personal injustice" to deny a person the "ordinary privilege of having his voice reckoned in the disposal of affairs in which he has the same interest as other people". He thus considered that each person should have "his opinion counted at its worth", though, as he made clear, "not at more than its worth". ${ }^{234}$ Anticipating critiques, Mill contended that "no one but a fool" would feel offended by his proposal because all accept that there are others whose opinion "is entitled to a greater amount of consideration" than theirs. ${ }^{235}$

Democratic theorists have challenged Mill's position from a variety of angles. Charles Beitz has dismissed Mill's belief that only a fool would feel unfairly treated, arguing that political inequities, including unequal voting power, are "unfair to those whom it disadvantages", and will diminish the self-esteem of individuals when the inequities reflect other societal cleavages. ${ }^{236}$ Even if Mill's scheme produced superior outcomes (and having a tertiary education does not necessarily make one politically competent), ${ }^{237}$ Beitz considers therefore that the political inequalities that it rests on should lead to its rejection. Further, even if one accepts Mill's assumption that a well-educated population may tend to rule more wisely, David Estlund argues that it does not follow that they should be granted additional political power. Estlund's "demographic objection" recognises education is intimately tied to social, economic, and racial privileges, meaning that the educated portion of the population "may disproportionally have epistemically damaging features that countervail the admitted epistemic benefits of education". ${ }^{238}$ While educated people may be more likely to rule in the common good, if only a small subset of the population is educated, "it is very likely that they do systematically share certain interests" and will, therefore, favour those interests. ${ }^{239}$

\footnotetext{
${ }^{227}$ Mill, supra note 25, p. 46 (Ch 2).

228 T. Latimer, 'Plural Voting and Political Equality: A Thought Experiment in Democratic Theory' (online June 29, 2015) European Journal of Political Theory (2015) p. 4. DOI: 10.1177/1474885115591344

${ }^{229}$ Mill, supra note 25, p. 76 (Ch 3).

${ }^{230}$ Ibid., p. 201 (Ch 8). See also J. Rawls, A Theory of Justice (Harvard University Press, Boston, 1971) p. 204.

${ }^{231}$ Mill, supra note 25, p. 157 (Ch 6).

${ }^{232}$ Ibid., p. 145 (Ch 6). See also G. Duncan, Marx and Mill: Two Views of Social Conflict and Social Harmony (Cambridge University Press, Cambridge, 1973) p. 219.

${ }^{233}$ Mill, supra note 25, p. 199 (Ch 8).

${ }^{234}$ Ibid., p. 193 (Ch 8).

${ }^{235}$ Ibid., p. 202 (Ch 8).

${ }^{236}$ C. Beitz, Political Equality (Princeton University Press, Princeton, 1989) pp. 36-7.

${ }^{237}$ N. Urbinati, Mill on Democracy: From the Athenian Polis to Representative Government (University of Chicago Press, Chicago, 2002) p. 98.

${ }^{238}$ D. Estlund, Democratic Authority: A Philosophical Framework (Princeton University Press, Princeton, 2008) p. 215.

${ }^{239}$ Ibid., p. 218.
} 
The demographic objection to plural voting is persuasive, but the democratic one is determinative. Political decisions are legitimate only to the extent that everyone affected has the opportunity to participate equally; denying that by providing greater opportunities for some, defeats the very essence of democracy. ${ }^{240}$ Nonetheless, it is significant that although Mill did not seek to justify plural voting by reference to marginalised ascriptive minorities, his analysis can translate. For Mill, plural voting is a response to the 'infirmities and dangers' of representative government; ${ }^{241}$ a danger that is all too real for members of such groups, who are often the victims of partial interests at odds with a more broadly-conceived common good. Can this danger be ameliorated in a manner that "advance[s] democratic aspirations"? ${ }^{242}$

\subsubsection{Redistricting}

In almost all democracies, electorates are territorially delimited. ${ }^{243}$ These boundaries are, however, "not merely arbitrary lines drawn on a map", but "almost always... are cognizant of geography and demography". ${ }^{244}$ The practice is widespread: a largescale comparative survey of electoral boundary delimitation found 19 of 60 countries that delimit electorate boundaries, require their boundary authority to consider "communities of interest". ${ }^{245}$ Communities of interest can be conceived of in either geographic or likeminded dimensions. For example, groups living alongside a river or on one side of a mountain may share particular interests because they are a community, while groups with a similar political outlook or socioeconomic status, perhaps based on employment in a large mine, may form a community because of their shared interests. ${ }^{246}$ Of course, these dimensions are fluid and intersect: it is often impossible (and unnecessary) to tell whether one or the other is primary. Significantly, for territorially concentrated marginalised ascriptive groups, a community of interest criterion, means that electoral boundary commissions may draw electorates to maximise the group's opportunity to elect candidates of their choice.

Relevant communities of interest are context dependent. In the United States state of Alabama, legislative guidelines instruct the Permanent Joint Legislative Committee on Redistribution to "respect" the integrity of communities of interest. These are defined as including but not limited to "racial, ethnic, geographic, governmental, regional, social, cultural, partisan, or historic interests; county, municipal, or voting precinct boundaries; and commonality of communications". ${ }^{247}$ In Canada, the Supreme Court has confirmed that "factors like geography, community history, community interests and minority

\footnotetext{
${ }^{240}$ On the idea of public equality see Christiano, supra note 99. Cf. Latimer, supra note 228, p. 2 : 'it is not the case that, by definition, plural voting schemes are inegalitarian'

${ }^{241}$ Mill, supra note 25, p. 133 (Ch 6).

${ }^{242}$ A. Levine, 'Electoral Power, Group Power, and Democracy' in in J. Chapman and A. Wertheimer (eds), Majorities and Minorities: Nomos XXXII (New York University Press, New York, 1990) p. 250, 258.

${ }^{243}$ Rehfeld, supra note 220, pp. 3, 9. See pp. 209-239 for an argument in favour of non-territorially delimited electorates. As Rehfeld notes, his institutional structure would 'greatly increase the power of majorities to dominate': p. 216.

${ }^{244}$ N. Aroney, 'Democracy, Community, and Federalism in Electoral Apportionment Cases: The United States, Canada, and Australia in Comparative Perspective' 58 University of Toronto Law Journal (2008) p. 444.

${ }^{245}$ L. Handley, 'A Comparative Survey of Structures and Criteria for Boundary Delimitation' in L Handley and B. Grofman (eds), Redistricting in Comparative Perspective (Oxford University Press, New York, 2008) p. 256, 272-3.

${ }^{246}$ See T. Makse, 'Defining “Communities of Interest” in Redistricting Through Initiative Voting' 11 Election Law Journal (2012) p. 505.

${ }^{247}$ State of Alabama, 'Reapportionment Committee Guidelines for Congressional, Legislative and State Board of Education Redistricting’ (May 2011) Principle, IV.7(b).
} 
representation" may need to be taken into account. ${ }^{248}$ Electoral boundaries in Australia are delimited by the Redistribution Committee, an apolitical body consisting of the Australian Electoral Commissioner, and the relevant State or Territory's Australian Electoral Officer, Surveyor General and Auditor General. ${ }^{249}$ Subject to a rough equality in voting power, ${ }^{250}$ the Redistribution Committee "shall give consideration" to communities of interests, defined to include "economic, social and regional interests", within the proposed division. ${ }^{251}$

In the United States, political ideology is relevant for electoral districting. ${ }^{252}$ As a result of extreme racially-polarised voting, the 1990s saw a proliferation of majority-minority redistricting. Majority-minority districts are electorates where an ethno-cultural group (or groups) constitutes the majority of the electorate's population. In many cases, majorityminority districts are created to avoid or remedy violations of the Voting Rights Act 1965 prohibition on drawing electoral boundaries in order to diminish the ability of a racial or linguistic minority to elect candidates of their choice, ${ }^{253}$ a legacy of severe racial discrimination in many parts of the country. The creation of these seats was intended to ensure that such minorities are represented in the legislature in proportion to their population size, and led to a significant increase in representation of minority candidates. ${ }^{254}$

Delimiting electoral boundaries by communities of interest may be a historical accident, ${ }^{255}$ but it offers clear advantages for representative democracy. Indeed, empirical research suggests that it can diversify the viewpoints considered at the deliberative stage, ${ }^{256}$ as well as enhance citizen involvement in politics, ${ }^{257}$ and potentially perform an educative function in developing citizens' capacities. ${ }^{258}$ These twin benefits are drawn from the fact that this approach guarantees that significant minority groups will not be substantially impaired in electing representatives of their choice, ${ }^{259}$ ensuring that these groups have their voices heard in the processes of government, and making the "representative's task of articulating the interests of his or her constituents easier". ${ }^{260}$

Nevertheless, a number of problems exist with this institutional mechanism. First, while guaranteeing the presence of a candidate of the minority group's choice in the legislature, the value of redistricting is questionable. Gerrymandering can dilute the value of minority votes by dividing minorities into several electorates ('cracking'), or over concentrating minorities

\footnotetext{
${ }^{248}$ Reference re: Electoral Boundaries Commission Act (1991) 81 DLR (4 $\left.{ }^{\text {th }}\right)$ 16, 36 (emphasis added).

${ }^{249}$ R. Medew, 'Redistribution in Australia: The Importance of One Vote, One Value' in L. Handley and B. Grofman (eds), Redistricting in Comparative Perspective (Oxford University Press, New York, 2008) p. 97, 98.

${ }^{250}$ A 10 per cent tolerance limit to each district at the time of redistribution and a 3.5 per cent tolerance limit on projected population 3.5 years from the time of redistribution.

${ }^{251}$ Commonwealth Electoral Act 1918 (Cth) s 66(3)(b)(i).

${ }^{252}$ See Thornburg $v$ Gingles 478 US 30 (1986); Easley v Cromartie 532 US 234 (2001).

${ }^{253}$ Voting Rights Act of 196552 USC $\$ 10101$ (1965).

${ }^{254}$ G. May, Bending Toward Justice: The Voting Rights Act and the Transformation of American Democracy (Duke University Press, Durham, 2014) p. 154.

${ }^{255}$ A. Pollard, The Evolution of Parliament (Longmans, Green and Co, London, 1920) pp. 108-109

${ }^{256}$ J. Gardner, 'One Person, One Vote and the Possibility of Political Community' 80 North Carolina Law Review (2002) pp. 1246-7.

257 J. Courtney, Commissioned Ridings (McGill-Queen's University Press, Montreal, 2001) p. 204, 210.

${ }^{258}$ N. Schwartz, The Blue Guitar: Political Representation and Community (University of Chicago Press, Chicago, 1998) pp. 12-13.

${ }^{259}$ B. Grofman, 'Should Representatives be Typical of their Constituents?' in B. Grofman et al, (eds), Representation and Redistricting Issues (Lexington Books, Lexington, 1982) p. 97, 98.

${ }^{260}$ Handley, supra note 245, p. 275; R. Levy, 'Drawing Boundaries: Election Law Fairness and its Democratic Consequences' in J-C. Tham, B. Costar and G. Orr (eds), Electoral Democracy: Australian Prospects (Melbourne University Press, Melbourne, 2011) p. 57.
} 
into one electorate ('stacking' and 'packing'). ${ }^{261}$ In majority-minority electorates, this process wastes minority votes; in super-majority group electorates, it absolves representatives from needing to earn votes of ethno-cultural minorities, leading them to pay less attention to minority interests. ${ }^{262}$ Second, and more problematically, redistricting merely shifts the majority-minority schism from the electorate to the legislature. Absent a culture of reasoned deliberation, the majority may enact procedural amendments to weaken the ability of the minority to exercise equal power within the representative assembly.

Third, while redistricting is not necessarily limited to sizeable numerical minorities, such groups must reach a certain threshold before this mechanism will be effective. ${ }^{263}$ In Australia, the Constitution entrenches significant discrepancies in voting power in both the House of Representatives, ${ }^{264}$ and the Senate. ${ }^{265}$ Drawing on these sections, the High Court has confirmed that the right to vote does not require an equally powerful vote. ${ }^{266}$ Equally, in Canada, the Supreme Court has accepted considerable variations in population of ridings between and within provinces. ${ }^{267}$ In the most recent federal election, for example, Niagara Falls, Ontario had over 2.4 times the number of electors as Kenora, Ontario. ${ }^{268}$ Nonetheless, it is clear that redistricting privileges spatially defined groups and offers little for territorially dispersed ethno-cultural minorities. Perhaps proportional representation offers a fairer alternative.

\subsubsection{Proportional Representation}

The redistricting process examined above takes for granted geographically defined groups as the basis of electoral representation. But in accepting communities of interests as relevant to redistricting, electoral systems acknowledge that representation can be based upon other types of groups. Significantly, because single-member territorial electorates can subsume minority interests, geography "may not be the most salient characteristic on which to base group representation". ${ }^{269}$ Many democratic theorists therefore advocate proportional representation (PR) in multi-member electorates as an alternative to single-member territorially-based electorates; John Stuart Mill, for example, considered that "all interests or classes of any importance" should have a voice in the representative assembly. ${ }^{270}$ While it is fair that the majority should outvote and prevail over the minority (Mill did not advocate granting veto power to minority groups), no substantial group or interest in society should be denied the opportunity to express its view. For Mill, ensuring that "every opinion which exists in the

\footnotetext{
${ }^{261}$ On this see R. Holden, 'Voting and Elections: New Social Science Perspectives' 12 Annual Review of Law and Social Science (2016) p. 255.

${ }^{262}$ D. Lublin, The Paradox of Representation (Princeton University Press, Princeton, 1997). In fact, as Rehfeld notes, 'the marginalisation of minority representatives from homogenous constituencies is... arguably endorseable based on democratic values': Rehfeld, supra note 220, p. 236.

263 Though note at the federal level in the United States, the Supreme Court has held that the Constitution demands strict equality of voting power: Reynolds v Smith (1964) 377 US 533. At state level, the Supreme Court has approved departures from strict equality of up to 10 per cent in order to protect communities of interest: Miller v Johnson 515 US 900, 919-20 (1995).

${ }^{264}$ Constitution of Australia (1901) s 7.

265 Constitution of Australia (1901) s 24.

${ }^{266}$ McKinlay v Commonwealth (1975) 135 CLR 1; McGinty v Western Australia (1996) 186 CLR 140.

${ }^{267}$ Reference re: Electoral Boundaries Commission Act (1991) 81 DLR (4 $\left.{ }^{\text {th }}\right) 16$.

${ }^{268}$ Niagara Falls, Ontario: 101,505 electors; Kenora, Ontario: 42,138 electors.

${ }^{269}$ L. Guinier, 'The Supreme Court, 1993 Term: '[E]racing Democracy: The Voting Rights Cases' 108 Harvard Law Review (1994) p. 127. Rehfeld, supra note 220, p. 159 (arguing that there is no reason 'only territorially contiguous interests are most relevant to national politics').

${ }^{270}$ Mill, supra note 25, Ch 7. See also A. Lijphart, 'Constitutional Choices for New Democracies' 2 Journal of Democracy (1991) p. 75.
} 
constituencies" is heard in deliberation, ensures that decisions which command the greatest respect of "all" are reached. ${ }^{271}$

PR aims to achieve this in a manner consistent with democratic equality. As noted above, plural voting regimes treat citizens unequally by distributing suffrage inequitably. In contrast, proportional voting systems treat citizens equally by distributing suffrage equally: all citizens have the same number of votes, and the legislative body reflects "the range of opinions and interests within the public at large". ${ }^{272}$ Simply, if 15 per cent of the electorate support a particular political party, that party should receive roughly 15 per cent of seats; "the majority should enjoy a majority of the power, but the minority should also enjoy some power too". 273

Proportional and semi-proportional representation systems are common throughout the world. ${ }^{274}$ Although there is considerable institutional variety, the two most common approaches are Party List PR and Single Transferable Vote (STV). Under the former system, parties make lists of candidates and parties win seats in proportion to the number of votes they receive. In closed lists, the party fixes the order in which the candidates will be assigned seats; in open list systems, electors may indicate preference among the candidates. In contrast, under STV systems, electors allocate one vote to each candidate, but each voter may register an ordinal preference ranking of candidates. While Party List PR and STV are most common, various alternative arrangements exist. One controversial semi-proportional voting system has been proposed by Lani Guinier: cumulative voting.

Cumulative voting is a multiple-winner voting system intended to promote more proportional representation than winner-take-all elections. Similarly, to ordinary proportional voting, rather than 'one person, one vote', cumulative voting adopts the principle of 'one person, $n$ votes', where $n$ is the number of representatives to be elected. Unlike STV, however, cumulative voting allows electors to indicate the intensity of their preferences, by 'cumulating' or 'plumping' all of their votes for one candidate. That is, if there are 12 seats available, electors can choose to vote for 12 separate candidates, to give six votes each to two candidates, or give 12 votes to one candidate. As Guinier explains, this system allows politically cohesive marginalised ascriptive groups to pool their votes to secure the election of a representative that reflects their interests. ${ }^{275}$

While Guinier's proposal is divisive, proportional or semi-proportional representation offers a number of advantages over geographically defined electorates. First, as proportional representation is interest-based, it allows voters to self-define their identities and constituencies, minimising the number of votes "wasted" by being cast in safe-seats. ${ }^{276}$ For marginalised ascriptive groups, the interest-based nature of proportional representation does not lock individuals into a minority identity, ${ }^{277}$ or require the state to single out minorities for

\footnotetext{
${ }^{271}$ Mill, supra note 25, p. 165 (Ch 7).

${ }^{272}$ L. Guinier, 'Groups, Representation, and Race Conscious Districting: A Case of the Emperor's New Clothes'

71 Texas Law Review (1993) p. 1638.

${ }^{273}$ L. Guinier, The Tyranny of the Majority: Fundamental Fairness in Representative Democracy (The Free Press, New York, 1994) pp. 14, 152.

${ }^{274}$ List PR is the most common electoral system in the world: A. Reynolds, B. Reilly and A. Ellis (eds), Electoral System Design: The New International IDEA Handbook (Institute for Democracy and Electoral Assistance, Stockholm, 2006) pp. 30-31.

275 Guinier, supra note 273, p. 14.

${ }^{276}$ Rehfeld considers concern over 'wasted votes' a ‘trivial concern': See Rehfeld, supra note 220, pp. 194-5.

277 Ibid., p. 16; D. Schultz, Election Law and Democratic Theory (Ashgate, Farnham, 2014) p. 193.
} 
"special protection", ${ }^{278}$ as redistricting, plural voting regimes, or reserved seats do. Secondly, empirically, political scientists have demonstrated that proportional representation can enhance the presence of dispersed ethno-cultural minorities in the representative assembly, ${ }^{279}$ though evidence is inconsistent over whether this extends to enhancing representation of concentrated minority groups. ${ }^{280}$ Quite apart from the fact that heterogeneous decisionmaking bodies make better decisions, ${ }^{281}$ this accords with the democratic ideal of equal influence and control. ${ }^{282}$ Finally, unlike plural voting systems, proportional representation achieves this outcome in a manner consistent with democratic equality.

Proportional and semi-proportional electoral systems provide ethno-cultural minorities with a greater opportunity to elect a representative of their choice. However, a fundamental problem remains. As the justice of these systems lies within a "claim of quantitative accuracy" 283 these electoral systems offer little for extreme minorities whose population size does not easily translate into a presence in the legislature, or minorities dispersed across political subunits. Paradoxically, these marginalised ascriptive groups may be most at risk from a domineering (or even respectful) persistent electoral majority. For these groups, a different electoral system is required.

\subsubsection{Reserved Seats}

The three mechanisms adopted above aim at ensuring members of marginalised ascriptive groups have an opportunity to elect a representative of their choice. Reserved seats go one step further, by ensuring that members of these groups are able to do this. This is not a rare institutional choice; more than thirty countries reserve seats in their national parliaments for representatives of ethno-cultural minorities. ${ }^{284}$ There are significant variations in design; reserved seats may be filled through competitive election in specially created districts, through election by voters registered on separate rolls, by group members receiving more votes in general elections, or through designation by political parties. ${ }^{285}$ The New Zealand model, for example, utilises two electoral rolls: a general roll and a Māori roll. Any person who identifies as being of Māori descent can elect to be placed on the Māori roll. Every five years, all registered Māori electors have the opportunity to choose whether to be included on the Māori or general roll. Following finalisation, the number of Māori electorates is determined so that each electorate is roughly equivalent to that of a general seat. In the most recent election, 7 Māori seats were established (out of 71). While 7 seats does not reflect the

\footnotetext{
${ }^{278}$ R. Pildes and K. Donoghue, 'Cumulative Voting in the United States' University of Chicago Legal Forum (1995) p. 255.

${ }^{279}$ See Reynolds, Reilly and Ellis (eds), supra note 274, p. 61; D. Cooper, 'The Potential of Cumulative Voting to Yield Fair Representation' 19 Journal of Theoretical Politics (2007) p. 277; D. Brockington et al, 'Minority Representation under Cumulative and Limited Voting' 60 The Journal of Politics (1998) p. 1122.

${ }^{280}$ R. Moser, 'Electoral Systems and the Representation of Ethnic Minorities' 40 Comparative Politics (2008) p. 289; W. Wagner, 'Electoral Systems and the Representation of Minorities: The Case of Ethnic Albanians in Macedonia' (Paper presented for presentation at the Peace Science Society/International Studies Association Joint International Conference, Budapest, June 27-29, 2013) p. 11.

${ }^{281}$ On the idea that deliberation between conflicting views is the best means for discovering the truth see above Pt III.B.1. See also J.S. Mill, On Liberty (J.W. Parker \& Son, London, 1859) p. 20; Aristotle, supra note 21, pp. 90-91 (Bk III, Ch 15).

${ }^{282}$ Urbinati, supra note 52, p. 41: 'democratic control must be vested in a collective body that ought ideally to profit from the voice of "every citizen".

${ }^{283}$ Ibid. Cf. Williams, supra note 17, p. 3 arguing that the claim is reparative justice rather than equality.

${ }^{284}$ M. Krook and D. O’Brien, 'The Politics of Group Representation: Quotas for Women and Minorities Worldwide' 42 Comparative Politics (2010) p. 253.

${ }^{285}$ M. Htun, 'Is Gender Like Ethnicity? The Political Representation of Identity Groups' 2 Perspectives on Politics (2004) p. 440.
} 
proportion of New Zealanders who identify as being of Māori descent (approximately 15 per cent), not all Māori's elect to enrol on the Māori roll.

Mirna Jusic and Nenad Stojanovic contend that there are two democratic justifications for reserved seats. ${ }^{286}$ On the one hand, liberal multiculturalists make a normative argument that ethno-cultural minorities should be guaranteed representation to ameliorate legacies of discrimination and marginalisation, ${ }^{287}$ or because fairer descriptive representation will increase their "context of choice", ${ }^{288}$ and ensure they are heard equally in political decisions. ${ }^{289}$ On the other hand sit pragmatic arguments, which see reserved seats as improving the quality of democratic decisions, ${ }^{290}$ or as necessary to promote stability in multiethnic states. ${ }^{291}$ Nonetheless, many theorists question whether reserved seats achieve these benefits. Pragmatically, concerns abound particularly over imposing group identity and ossifying lines of group cleavage, potentially entrenching intergroup conflict. ${ }^{292}$ Normatively, others suggest that reserved seats may distort the democratic principle of one-person, onevote. ${ }^{293}$ On the first point, as many scholars have argued, group recognition does not foment cleavages but acknowledges their existence within the community. By giving voice to minority groups, it is hoped that more equitable decision-making will be reached. The normative arguments are also unpersuasive. As the previous sections have illustrated, electoral systems already depart from strict equality of voting power in order to protect communities of interests, and including representatives of all politically relevant groups is a normatively desirable goal that aspires to the democratic ideal of collective self-rule. ${ }^{294}$

Reserved seats are potentially particularly advantageous for marginalised ascriptive groups as they present the opportunity for members of such groups to "set the agenda". ${ }^{295}$ Indeed, in her examination of "the politics of presence", Anne Phillips has noted that the real value of presence lies in the way it may "transform the political agenda" by expanding the range of ideas and rendering visible what was invisible. ${ }^{296}$ While we must be careful not to fall into naïve essentialism that equates shared experience with shared belief, ${ }^{297}$ experiences are formative and the views and interests of marginalised groups may be inaccessible to members of the dominant community. ${ }^{298}$ Significantly, legislators elected through reserved seats, rather than intraparty quotas, may operate independent of political parties, reducing partisan constraints and enhancing the opportunity for collaboration. ${ }^{299}$ Encouragingly, limited

\footnotetext{
${ }^{286}$ M. Jusic and N. Stojanovic, 'Minority Rights and Realpolitik: Justice Based vs. Pragmatic Arguments for Reserving Seats for National Minorities’ 14 Ethnopolitics (2015) pp. 404-5.

${ }^{287}$ Williams, supra note 17; Young, supra note 86, p. 184.

${ }^{288}$ Kymlicka, supra note 86.

${ }^{289}$ Phillips, supra note 96, pp. 70-71, 176; A. Reilly, 'Dedicated Seats' 2 Balayi (2001) p. 77.

290 J. Mansbridge, 'Should Blacks Represent Black and Women Represent Women? A Contingent "Yes"” 61 The Journal of Politics (1999) p. 628.

${ }^{291}$ Lijphart, supra note 143.

292 Rehfeld, supra note 220, p. 211.

${ }^{293}$ See concerns raised in a New South Wales, Australia, parliamentary report: Legislative Council Standing Committee on Social Issues, Parliament of New South Wales, Enhancing Aboriginal Political Representation: Inquiry into Dedicated Seats in the New South Wales Parliament (1998) p. 49.

${ }^{294}$ C.I. Zuber, 'Reserved Seats, Political Parties, and Minority Representation' 14 Ethnopolitics (2015) p. 390.

${ }^{295}$ H. Catt and M. Murphy, Sub-State Nationalism: A Comparative Analysis of Institutional Design (Routledge, New York, 2002) p. 49.

${ }^{296}$ Phillips, supra note 96, p. 176, see also pp. 70-71.

${ }^{297}$ Ibid., p. 52-56. See also above Part II.B.

${ }^{298}$ See Williams, supra note 17, p. 133.

${ }^{299}$ Tiffany Barnes, Gendering Legislative Behaviour (Cambridge University Press, Cambridge, 2016) p. 230 citing M. Htun and J. Ossa, 'Political Inclusion of Marginalised Groups: Indigenous Reservations and Gender Parity in Bolivia' 1 Politics, Groups, and Identities (2013) p. 4. See also Htun, supra note 285, p. 440; Sarah
} 
empirical evidence suggests reserved seats have a positive, though modest, effect in strengthening the voice of political minorities. ${ }^{300}$

\section{Conclusion}

Majority rule may be the "least bad" method for resolving disagreements within a society, ${ }^{301}$ but undifferentiated majoritarianism entails real risks for marginalised ascriptive groups. Thankfully then, while majority rule is a central element of democracy, democracy is more than majority rule. Democracy is collective self-rule. It requires institutional forms that ensure all citizens, whether members of a dominant ethno-cultural community or not, have an opportunity to be heard in the processes of government. That is, to have a say in government in a manner that allows them to impose a direction on that government.

This paper has provided a taxonomy of legal and political institutional arrangements and processes aimed at providing numerical minorities who constitute marginalised ascriptive groups, with the capacity to have their interests heard in the processes of government. These arrangements differ in form, ranging from attempts to insulate minority interests from decisions of the majority, reconceptualising democracy away from preference aggregation, or amending the machinery of majoritarian processes to enhance the ability of ethno-cultural minorities to elect representatives of their choice. Notwithstanding these distinctions, each approach is grounded in a conception of democracy as "government for the people, not for a majority of the people", and a belief that "a minority has a right to have its losses taken into account". ${ }^{302}$ This democratic position is reflected in the Supreme Court of Canada's 1998 decision Reference re Secession of Quebec, a complex case - and one identified by Hirschl as an element of "judicialisation of mega-politics" 303 _ concerning the political relationship of a ethno-cultural minority and majority:

A democratic system of government is committed to considering those dissenting voices, and seeking to acknowledge and address those voices in the laws by which all in the community must live. ${ }^{304}$

Liberal democratic states' failure to hear the concerns of their constituents has presaged a recent drift towards authoritarian nationalism. In setting out institutional arrangements aimed at realising democracy's promise, it is hoped that constitutional lawyers, democratic theorists, and policy makers will reimagine political and legal processes and mechanisms that enable all citizens to be heard in the processes of government. This has great potential to assist with the resolution of recurrent problems across the globe.

\footnotetext{
Maddison, 'White Parliament, Black Politics: The Dilemmas of Indigenous Parliamentary Representation' 45 Australian Journal of Political Science (2010) p. 663.

${ }^{300}$ E. Hodzic and B. Mraovic, 'Political Representation of Minorities in Bosnia and Herzegovina: How Reserved Seats Affect Minority Representatives' Influence on Decision-Making and Perceived Substantive Representation' 15 Ethnopolitics (2015) p. 418.

${ }^{301}$ Allan, supra note 2, p. 538.

${ }^{302}$ A. Ware, 'The Concept of Political Equality: A Post-Dahl Analysis' 29 Political Studies (1981) p. 405. See also R. Brown, 'The Logic of Majority Rule' 9 Journal of Constitutional Law (2006) p. 23

${ }^{303}$ R. Hirschl, 'The New Constitutionalisation and Judicialisation of Pure Politics Worldwide' 75 Fordham Law Review (2006) pp. 741-2.

${ }^{304}$ Reference re Secession of Quebec [1998] 2 SCR 217, p. 257, paragraph 68
} 